\title{
LA LLAMADA LEY MORDAZA: LA LEY ORGÁNICA 4/2015 DE PROTECCIÓN DE LA SEGURIDAD CIUDADANA
}

\author{
JUAN MARÍA BILBAO UBILLOS \\ Catedrático de Derecho constitucional \\ Universidad de Valladolid
}

\author{
SUMARIO \\ I. Antecedentes. \\ II. El contenido de la LOPSC.
}

\section{ANTECEDENTES}

\section{El anteproyecto de LOPSC}

El Anteproyecto de LOPSC fue aprobado por el Gobierno en noviembre de 2013 ${ }^{1}$. En su Exposición de Motivos se desgranan algunas de las razones que justifican esta iniciativa, que implica la sustitución de la LOSC 1992 por un nuevo texto completo: «el simple transcurso del tiempo,... los cambios sociales ope-

1 En su reunión del 29 de noviembre de 2013, el Consejo de Ministros recibió un informe del Ministro del Interior sobre el Anteproyecto de LOPSC. De acuerdo con la referencia oficial de dicha sesión, «el nuevo texto es oportuno, conveniente y necesario porque va en consonancia con la actual reforma del Código Penal, por la existencia de abundante jurisprudencia que ha configurado un sistema más garantista y por la constatación de los cambios en nuestra sociedad en estos últimos veintidós años». Se refiere al proyecto de reforma del Código Penal que se estaba tramitando entonces en las Cortes, en el que desaparecían las faltas como infracción penal, al convertirse algunas en delitos leves y otras en infracciones administrativas. Se trata, además, de un texto «firmemente comprometido con los derechos fundamentales y libertades que el ordenamiento jurídico reconoce a los ciudadanos para que la violencia y el vandalismo tengan una respuesta legal». Aunque se insiste en que en ningún caso se trata de sancionar más, sino de sancionar mejor y con más garantías («la nueva regulación es más clara y reduce el margen de discrecionalidad con definiciones más precisas que contribuyen a mejorar la seguridad jurídica»), lo cierto es que, como luego veremos, el Anteproyecto eleva el número de faltas leves recogidas en la LOPSC de 1992 de 10 a 20, mientras las graves pasan de 16 a 31. Además, prevé de manera expresa 7 infracciones muy graves. 
rados en nuestro país, las nuevas formas de poner en riesgo la seguridad y la tranquilidad ciudadanas, los nuevos contenidos que las demandas sociales incluyen en este concepto, la imperiosa necesidad de actualización del régimen sancionador o la conveniencia de incorporar la jurisprudencia constitucional en esta materia justifican sobradamente un cambio legislativo».

Se alude, entre otros motivos, a una demanda creciente de seguridad que hay que atender, lo que no se compadece con los datos demoscópicos, que dan pie a pensar más bien que los españoles no estaban entonces, ni están ahora, especialmente preocupados por la inseguridad. En las encuestas del CIS de los últimos tres años no llega al $0.5 \%$ el porcentaje de ciudadanos que consideran la inseguridad como el principal problema del país ${ }^{2}$.

Es verdad que la nueva ley es más exhaustiva y sistemática que la de 1992. Incluye, por ejemplo, un primer capítulo sobre las disposiciones generales que proporciona un marco general para la actuación de las autoridades públicas en relación con la seguridad ciudadana que no existía hasta ahora. También se regulan las obligaciones relacionadas con la documentación y la identificación personal o los registros corporales externos. Pero no son pocas las disposiciones cuya constitucionalidad resulta dudosa. Y que provocaron desde un principio un aluvión de severas críticas. Para M. Presno, uno de los primeros en dar la voz de alarma, el Anteproyecto reúne las características del Derecho Administrativo sancionador del enemigo: anticipa la punibilidad administrativa (se tipifican conductas que pueden perturbar la «tranquilidad» ciudadana), aumenta las sanciones de manera desproporcionada y disminuye las garantías procesales de los ciudadanos ${ }^{3}$.

En esa misma onda se inscribe el extenso Informe del Consejo General del Poder Judicial, emitido en su reunión del día 27 de febrero de 2014: «el Ante-

2 En efecto, las series del Barómetro mensual del CIS revelan que el porcentaje de encuestados que de forma espontánea señalan la inseguridad ciudadana como el principal problema del país oscilan entre el 0.0 de julio de 2014 y el 0.3 de marzo de 2015 y casi siempre se sitúa en el 0.1 o 0.2 . Sumando las respuestas de quienes perciben la inseguridad como segundo o tercer problema, el total de encuestados que mencionan este problema entre los tres principales del país no llega en ningún caso al 3\% (2.6\% en mayo y octubre de 2013, pero sólo un $1.7 \%$ en noviembre de 2014). Las cifras no cambian mucho cuando se les pregunta cuáles son los tres problemas que personalmente le afectan más. El porcentaje de los que responden espontáneamente que la inseguridad es el problema que más les afecta se sitúa entre el 0.3 — en mayo de 2015 — y el 0.5 —en julio de 2014 - Pero son menos del $2 \%$ los encuestados que lo señalan como uno de los tres problemas principales (del 1.2 de marzo de 2015 al 1.7 de mayo de 2013).

3 «El primer anteproyecto de Ley Orgánica para la Protección de la Seguridad Ciudadana», Teoría y Realidad Constitucional, n. ${ }^{\circ}$ 34, 2014, pp. 269-292. A su juicio, el Anteproyecto opta, al menos en numerosos preceptos, por el Derecho administrativo del enemigo — protección de bienes jurídicos- y no por el Derecho administrativo del ciudadano — protección de las esferas de libertad— (p. 283). Entre estas primeras reacciones de rotundo rechazo, hay que anotar la del Comité Permanente de Jueces para la Democracia, que hizo público un documento: Orden público y restricción de libertades. Análisis de la reforma de la legislación penal y administrativa desde la perspectiva de la protección de los derechos fundamentales (Alcalá de Henares, 20 y 21 de febrero de 2014); la de Amnistía Internacional: España: El derecho a protestar, amenazado (https://www.es.amnesty.org/ paises/espana/documentos) y la de Greenpeace: No a la criminalización de la protesta pacífica (http://www. greenpeace.org/espana/es/Trabajamos-en/No-a-la-LeyAntiprotesta). 
proyecto sigue la línea marcada por el Proyecto de reforma del Código Penal, situándose en lo que se ha venido a llamar Derecho penal de la peligrosidad. Desde los axiomas de este derecho, la seguridad se convierte en una categoría prioritaria en la política criminal, como un bien que el Estado y los Poderes públicos han de defender con todos los medios e instrumentos a su alcance. Como consecuencia de ello, la Ley proyectada, por un lado, intensifica la acción preventiva, no solo del delito, sino también de las infracciones administrativas, y por otro, incrementa notablemente las infracciones contra la seguridad ciudadana» (p. 5).

Menos crítico es el tono general del Dictamen emitido por el Consejo de Estado. Para el supremo órgano consultivo, el Anteproyecto «guarda la prudente ponderación y contrapeso entre los valores de libertad y seguridad», sin perjuicio de las numerosas observaciones que a continuación se hacen al articulado ${ }^{4}$.

\section{El proyecto de LOPSC}

El Gobierno remitió a las Cortes el proyecto de LOPSC en julio de $2014^{5}$. Este texto corrige algunos de los defectos y excesos detectados en el Anteproyecto por los órganos que fueron consultados e informaron sobre el mismo. En muchos aspectos la redacción original fue suavizada o depurada y algunas previsiones fueron suprimidas. Me limitaré a dar cuenta de las modificaciones más relevantes introducidas en el capítulo V (Régimen sancionador) ${ }^{6}$.

4 Dictamen 557/2014 sobre el Anteproyecto de Ley Orgánica de Protección de la Seguridad Ciudadana, emitido por unanimidad por la Comisión Permanente en la sesión celebrada el día 26 de junio de 2014 , p. 11. El Consejo de Estado sale al paso de dos de las objeciones más extendidas entre los críticos de la nueva Ley. Recuerda, por un lado, que la eficaz protección de las personas y los bienes no se consigue sólo persiguiendo al agresor una vez cometida la agresión y tratando de restaurar los daños y lesiones ocasionadas, sino también mediante medidas preventivas dirigidas a evitar los riesgos que amenazan la paz pública en nuestros días, siempre que se respete el contenido esencial de los derechos y libertades constitucionales. Y sostiene, por otro, que la utilización de conceptos jurídicos indeterminados, categoría bien conocida en el Derecho público, no equivale a «vaguedad»e «imprecisión». Dado que el legislador no puede prever detalladamente todas y cada una de las circunstancias del caso al que hay que aplicar la ley, es razonable el recurso a los conceptos jurídicos indeterminados. Ello no supone abrir la puerta a la arbitrariedad sino dejar un ineludible margen a la discrecionalidad del operador jurídico (en este caso, las autoridades responsables de la seguridad ciudadana), una discrecionalidad que puede ser controlada por la jurisdicción como toda la actividad administrativa sin excepción (artículo 106.1 CE).

5 BOCG, Congreso, X Leg., Serie A, num. 105-1, de 25 de julio de 2014, p. 1 y ss.

6 Aunque no es el único capítulo en el que se registran cambios. Por poner sólo un ejemplo, en el artículo 4.3 (Principios rectores de la acción de los poderes públicos en relación con la seguridad ciudadana), se disponía que la intervención de las autoridades y órganos competentes «se justifica por la existencia de riesgo o amenaza concretos, o de un comportamiento objetivamente peligroso que, razonablemente, sea susceptible de provocar un perjuicio real para la seguridad ciudadana y, en concreto, vulnerar normas del ordenamiento jurídico, atentar contra los derechos y libertades individuales y colectivas y demás bienes jurídicos protegidos, o alterar el regular funcionamiento de las instituciones públicas». Esta formulación, como advirtió el CGPJ en su Informe, resultaba excesivamente amplia y no se adecuaba al concepto constitucional de seguridad ciudadana, porque el mero incumplimiento de una norma o el atentado no violento contra un bien jurídico 
En primer lugar, en lo relativo a los sujetos responsables, aunque la responsabilidad por las infracciones cometidas recaerá directamente en el autor del hecho (art. 29.1), el apartado 4 de este mismo precepto disponía que «a los efectos de este artículo, se considerarán autores a quienes realicen los hechos por sí solos o conjuntamente o por medio de otros de quienes se sirva con instrumento, así como los que induzcan directamente a otros a ejecutarlos y los que cooperen a su ejecución con un acto sin el cual no se habría realizado la infracción». Se acoge pues un concepto amplio de autor, en términos análogos al Código Penal (art. 28) ${ }^{7}$. Pero este párrafo ya no figura en el artículo 30 del Proyecto.

Con respecto al catálogo de infracciones, el anteproyecto incluía entre las que se calificaban de muy graves «la convocatoria por cualquier medio o la asistencia a cualquier reunión o manifestación con finalidad coactiva e inobservancia de los requisitos previstos» en la LODR, desde que haya finalizado la campaña electoral hasta la finalización del día de la elección. Son las concentraciones promovidas por el movimiento 15-M (las que tuvieron lugar en la Puerta del Sol, por ejemplo) con motivo de las elecciones locales de 2011 las que están en la diana. Pero, como explica el CGPJ en su Informe, se trataría en todo caso de una infracción electoral que debería tipificarse en la LOREG y cuya sanción correspondería a la Junta Electoral competente. Si a ello se añade que la expresión «con finalidad coactiva» resulta excesivamente abierta (no se sabe cuál es la finalidad de esa coacción ni a quienes va dirigida), parece acertada la decisión de prescindir de esta infracción en el Proyecto ${ }^{8}$.

Otra infracción relacionada con el ejercicio del derecho de reunión que no pasó la criba es la prevista en el artículo 35.9 del Anteproyecto, que castigaba como infracción grave «la celebración de reuniones o manifestaciones en lugares de tránsito público portando armas u objetos contundentes susceptibles de causar daño, siempre que tales conductas no sean constitutivas de delito»". Desaparece asimismo la infracción consistente en «la participación en alteraciones de la seguridad ciudadana usando capu-

protegido no pueden justificar una intervención. Y en el Proyecto se eliminan ambos supuestos. Desaparece asimismo del artículo 24 del Proyecto la obligación de las empresas y personal de seguridad privada de colaborar eficazmente con las FCSE en la disolución de reuniones o manifestaciones, deber genérico que sí se establecía en el artículo 23 del Anteproyecto y había suscitado el «firme rechazo» del CGPJ en su Informe (p. 44)

7 La regla general en nuestro Derecho Administrativo sancionador es que las infracciones castigan únicamente al autor directo del hecho, resultando impunes la inducción y la cooperación necesaria.

8 Por las mismas razones se retiró del Proyecto la infracción prevista en el art. 35.8 del Anteproyecto ( "la perturbación del orden en un acto de campaña electoral, administración electoral, votación, escrutinio y recuento de votos no constitutiva de infracción penal o administrativa...».

9 El razonamiento del CGPJ (p. 62) es difícilmente rebatible: si el artículo 514.2 CP castiga a los asistentes a la reunión o manifestación que porten armas u otros medios igualmente peligrosos, respecto de ellos esa infracción resulta superflua. Y si lo que se pretende es el castigo de los organizadores o los demás asistentes a una manifestación en la que otros portan armas, ello supondría un indebido traslado de la responsabilidad a personas ajenas al hecho infractor, una exigencia de responsabilidad objetiva con infracción de los principios de culpabilidad y de personalidad de la sanción. 
chas, cascos o cualquier otro tipo de prenda u objeto que cubra el rostro, impidiendo o difcultando la identificación» (art. 35.2 del Anteproyecto $)^{10}$.

La depuración (parcial, en todo caso) del texto original del Anteproyecto es algo más visible en el capítulo de las infracciones relacionadas con las libertades de expresión e información. Se suprime, en primer lugar, la infracción grave prevista en el artículo 35.12, que sancionaba «las ofensas o ultrajes a España, a las comunidades autónomas y entidades locales o a sus instituciones, símbolos, bimnos o emblemas, efectuadas por cualquier medio, cuando no sean constitutivos de delito». Una conducta que ya está castigada como delito en el artículo $543 \mathrm{CP}$, por lo que carecía de sentido su tipificación como infracción administrativa ${ }^{11}$.

También planteaba problemas en relación con el principio de non bis in idem la infracción prevista en el artículo 35.16: "Las manifestaciones públicas, escritas o verbales, efectuadas a través de cualquier medio de difusión, así como el uso de banderas, símbolos o emblemas con la finalidad de incitar a comportamientos de alteración de la seguridad ciudadana, violentos, delictivos o que inciten, promuevan, ensalcen o justifiquen el odio, el terrorismo, la xenofobia, el racismo, la violencia contra la mujer, o cualquier otra forma de discriminación, siempre que no sean constitutivas de delito». Esta infracción se solapaba con alguna de las conductas sancionadas en el artículo $510 \mathrm{CP}$ y en los artículos 557.2 y 559 del Proyecto de reforma del CP. En cualquier caso, el CGPJ consideró excesiva la sanción de la incitación, que, como excepción a la impunidad general de los actos preparatorios, ha de delimitarse cuidadosamente. Y el Gobierno dio marcha atrás ${ }^{12}$.

Ante las severas críticas formuladas en el Informe del CGPJ, el Gobierno decidió eliminar algunas otras infracciones incluidas en el Anteproyecto, como la

10 Un tipo redundante, a juicio del CGPJ, porque sanciona al encapuchado que participe en una alteración de la seguridad, dando lugar a un concurso de normas entre este precepto y el que sancione la alteración de la seguridad que realiza el encapuchado, de manera que solo se castigará una de las infracciones.

11 Para M. Presno (op. cit. p. 288-290), «la represión de los actos de comunicación de los que muestran su desafección a las instituciones o a sus símbolos se extiende al derecho administrativo», a pesar de la posición preferente de la libertad de expresión en nuestro sistema constitucional y de la intensa protección dispensada por el TEDH al discurso político, aunque incluya expresiones ofensivas o molestas (vid., por ejemplo, su sentencia en el asunto Otegui Mondragón c. España). Más amplia aún es la interpretación de la libertad de expresión en la jurisprudencia del Tribunal Supremo de los Estados Unidos. Recuerda Presno que en el famoso asunto Texas $v$. Johnson (491 US 397, 1989) consideró que el ámbito de protección de la primera enmienda se extendía a determinadas conductas expresivas, como negarse a saludar la bandera o incluso quemarla, pese al enorme valor que tiene la bandera en ese país como símbolo de la nación. Pero por encima de ese valor ha de prevalecer el principio de que el Gobierno no puede prohibir a una persona ejercer su derecho a la libre expresión únicamente porque no está de acuerdo con su contenido. En resumidas cuentas, las expresiones ofensivas o ultrajantes para las instituciones o sus símbolos son parte del derecho fundamental a la libertad de expresión, «y muy débiles deben ser esas instituciones y símbolos si no son capaces de soportar una crítica semejante».

12 Tampoco tenía justificación, según el CGPJ, la infracción leve tipificada en artículo 36.6 del Anteproyecto: «las manifestaciones públicas efectuadas a través de cualquier medio de difusión cuya finalidad sean las injurias o calumnias a las instituciones públicas, autoridades, agentes de la autoridad o empleados públicos, cuando no constituyan delito». Se sancionaban las injurias o calumnias leves, que son conductas que no guardan relación con la protección de la seguridad ciudadana y suponen una limitación indebida de las libertades de expresión e información. 
prevista en el art. 36.18 («el entorpecimiento indebido de cualquier otro modo de la circulación peatonal que genere molestias innecesarias a las personas o el riesgo de daños a las personas o bienes»), de contornos ciertamente imprecisos, o en el art. 36.16 ( «la colocación no autorizada en la vía pública de elementos o estructuras no fijas, como tenderetes, pérgolas, tiendas de campaña, construcciones portátiles o desmontables u objetos análogos), una conducta, no vinculada directamente con la seguridad ciudadana, que afecta al uso de la vía pública, que es competencia municipal. La posible intromisión en la esfera de competencias de los entes locales explica también la supresión del art. 35.21 del Anteproyecto, que tipificaba como infracción grave «el consumo de bebidas alcobólicas en lugares, vías, establecimientos o transportes públicos cuando perturbe gravemente la tranquilidad ciudadana». Como bien se sabe, el consumo público de bebidas alcohólicas viene siendo regulado en muchas ordenanzas municipales, lo que da pie a la imposición de una doble sanción, con infracción del principio non bis in idem.

\section{La tramitación del proyecto de LOPSC en las Cortes Generales}

En relación con este proyecto, publicado en el BOCG de 25 de julio ${ }^{13}$, se presentaron 270 enmiendas, 9 de ellas a la totalidad de devolución ${ }^{14}$. El debate de totalidad, que se celebró el 16 de octubre de 2014 en el Pleno del Congreso ${ }^{15}$, se abrió con la intervención del ministro del Interior para presentar el texto en nombre del Gobierno. Reitera los argumentos ya desgranados en el Preámbulo para justificar la iniciativa. Por un lado, es patente la necesidad de actualizar y mejorar la ley vigente ${ }^{16}$, recogiendo la jurisprudencia emanada en los 23 años transcurridos desde su entrada en vigor, que ha delimitado con mayor precisión y mayores garantías el ejercicio de la potestad sancionadora de la Administración. Alude, por otro, al proyecto de ley de reforma del Código Penal, que despenaliza las faltas, de modo que determinadas conductas que hasta ahora eran merecedoras de reproche penal, pasarán a ser sancionadas como infracciones administrativas, con arreglo, eso sí, a un procedimiento con todas las garantías y sometido a con-

13 BOCG, Congreso de los Diputados, X Legislatura, Serie A, n. ${ }^{\circ} 105-1,25$ de julio de 2014, p. 1 y ss.

14 BOCG, Congreso de los Diputados, X Legislatura, Serie A, n. ${ }^{\circ}$ 105-2, 4 de noviembre de 2014, p. 1 y ss. Formularon enmiendas a la totalidad prácticamente todos los grupos, un dato muy significativo, dada la heterogeneidad política de este frente anti-LOPSC. Sometidas a votación conjunta se rechazarían por 144 votos a favor y 182 en contra.

15 DSCD, Pleno y Diputación Permanente, Año 2014, X Legislatura, n. ${ }^{\circ} 230$, p. 22 y ss.

16 Recuerda el ministro que con este proyecto dan cumplimiento al mandato derivado de la aprobación por el Pleno del Congreso, en su sesión de 26 de julio de 2012, de una moción consecuencia de una interpelación del GP Catalán (CIU), que, entre otras cosas, instaba al Gobierno a promover la modificación de la LOPSC para ofrecer una mejor respuesta a los episodios de violencia urbana y actualizar el catálogo de infracciones y sanciones. 
trol judicial. Se trata, en definitiva, de dotar a las Fuerzas y Cuerpos de Seguridad de un marco jurídico adecuado para que puedan cumplir con la mayor eficacia el mandato que les confiere la Constitución en su artículo 104.

Reconoce Fernández Díaz que el texto originario se ha enriquecido gracias a las observaciones contenidas en los dictámenes e informes de los órganos que fueron consultados (CGPJ, Consejo de Estado, Consejo Fiscal, AEPD) y las aportaciones de diversas instituciones, entidades y asociaciones ${ }^{17}$, lo que reafirma su convicción de que es un proyecto "profundamente garantista», que tiene «un perfecto encaje en nuestro sistema constitucional» ${ }^{18}$. E insiste, a este respecto, en que la seguridad jurídica se incrementa notablemente porque se definen con más precisión las infracciones.

Los argumentos esgrimidos por el ministro fueron rebatidos por los portavoces de todos los grupos de la oposición, que mantuvieron una postura beligerante, extremadamente crítica, tanto en el Congreso como en el Senado. En mi primer lugar, el simple transcurso del tiempo no es una razón suficiente para derogar la ley de $1992^{19}$. En segundo lugar, no existe, a su juicio, una demanda ciudadana de mayor rigor a la hora de garantizar la seguridad ciudadana, entre otras cosas, porque tenemos unas tasas de criminalidad relativamente bajas, que se han reducido incluso en los últimos años. En tercer lugar, lejos de incorporar la jurisprudencia acumulada en curso de las dos últimas décadas, el proyecto contradice abiertamente algunas de esas directrices jurisprudenciales. Y supone una involución, un retroceso, en el tratamiento de los conflictos que afectan a la seguridad ciudadana.

En resumidas cuentas, para los grupos de la oposición, el objetivo de la nueva ley, que se ha ganado a pulso el sobrenombre de ley mordaza, es censurar, silenciar, criminalizar y reprimir cualquier crítica o expresión de protesta ${ }^{20}$ e instaurar un Estado policial ${ }^{21}$, en el que las fuerzas de seguridad van a disponer de más fa-

17 El portavoz del Grupo Popular en el Senado, Aznar Fernández, llegó a decir en el curso del debate en el Pleno, que el proyecto "prácticamente no se parece en nada a aquel inicial anteproyecto» (DSS, X Legislatura, n. ${ }^{\circ} 147,12$ de marzo de 2015, p. 14086).

18 DSCD,... p. 28. Reta a los portavoces de la oposición a que le indiquen qué derecho se restringe o conculca y les reprocha que hagan una «caricatura» del texto (DSCD... p. 45). El portavoz del Grupo Popular denuncia, por su parte, el «frente común» contra el PP con la excusa de la ley, con el fin de generar una alarma artificial mediante un discurso de panfleto incendiario, de confrontación gratuita, basado en falsedades y etiquetas fáciles y demagógicas (DSCD,...p. 54).

19 Para Rosa Díez (UPyD), por ejemplo, es una ley innecesaria, que recorta derechos y elimina garantías (DSCD..., p. 36). El grupo de CIU sí considera necesaria la nueva regulación, pero no comparte ni sus principios inspiradores ni su contenido en varios aspectos. Para otros grupos, habría sido suficiente una modificación parcial.

20 A la recurrente acusación de que con la ley se intenta acallar y criminalizar la protesta ciudadana y desactivar así las movilizaciones en contra de los recortes sociales, el ministro replica: «¿Usted cree de verdad que a estas alturas, cuando llevamos 90.000 manifestaciones a lo largo de esta legislatura, nos va a preocupar hacer una ley para reprimir un derecho fundamental como el de reunión y manifestación, que en la inmensa mayoría de los casos se ejerce...libre y pacíficamente?»(DSCD, ...p. 48).

21 Expresión utilizada, entre otros, por J. Tardá, de ERC (DSCD, .., p. 30). 
cultades discrecionales de intervención, facultades que van a poder ejercer, además, sin someterse a ningún control efectivo, sin rendir cuentas, porque lo que se propicia es justamente la impunidad de los agentes del orden y la indefensión de los ciudadanos.

A nadie puede sorprender el tono crítico de las intervenciones de los portavoces de la oposición, que aluden constantemente al rechazo que suscita el proyecto en amplios sectores de la sociedad y se comprometen además, públicamente, a derogar la ley en la próxima legislatura. Llama la atención, en cambio, la indigencia argumental de algunos discursos repletos de gruesas descalificaciones, que no entran a analizar el texto. Da la impresión de que se mantiene por pura inercia el diapasón de la crítica contra un anteproyecto que, como hemos visto, sí merecía una respuesta contundente. Sirva como botón de muestra la breve intervención de J. Baldoví, en representación de Compromis. Las 18 líneas del Diario de Sesiones (p. 32) que transcriben sus palabras pueden resumirse así: «Hoy el PP con sus votos aprobará una ley antidemocrática, anticonstitucional y antisocial. Una ley que supone el mayor recorte de derechos desde que no teníamos ningún derecho...; una ley sancionadora, punitiva, desproporcionada y abusiva (...) que busca imponer multas astronómicas a los colectivos organizados (...) esta ley nos huele a la Ley de Orden Público de 1959». La referencia a esta ley franquista me parece fuera de lugar, un despropósito. Y no es el único diputado que incurre en tal desmesura: también lo hacen los portavoces socialistas Soraya Rodríguez ${ }^{22}$ y Trevín y el portavoz de la Izquierda Plural, Sixto Iglesias ${ }^{23}$. No faltan razones para criticar el proyecto, de forma virulenta incluso, pero hay líneas rojas que no se deberían cruzar. Me temo que sus señorías no han leído la LOP de 1959.

Las 270 enmiendas parciales formuladas por diputados y grupos del Congre$\mathrm{so}^{24}$ fueron examinadas por la ponencia encargada de estudiar el proyecto, que emitió el correspondiente informe ${ }^{25}$. La ponencia acordó incorporar al texto un considerable número de enmiendas (80) de casi todos los grupos, entre otras, todas las presentadas por el Grupo Popular (de mejora técnica en su mayoría) y bastantes de las suscritas por el Grupo Vasco (PNV).

Ciñéndonos a las modificaciones de mayor alcance, se suprimen los apartados 16 y 18 del artículo 36 y el apartado 14 del artículo $37^{26}$. Y sobre la base de una enmienda formulada por el propio Grupo Popular, la 191, se añade, por mayoría,

22 Para esta diputada, la ley, que debería llamarse Ley de represión ciudadana, destila desde su origen demasiadas similitudes con la LOP de 1959 (DSCD, cit., p. 42). Sus compañeros en el Senado, A. Batalla (GSS) y Bruguera (PSC-Entesa), afirmaron también que la ley nos retrotrae a la LOP.

23 DSCD, Pleno, Año 2014, X Legislatura, n. ${ }^{\circ} 248,11$ de noviembre de 2014, p. 78.

24 BOCG, Congreso, X Legislatura, Serie A, n. ${ }^{\circ}$ 105-2, 4 de noviembre de 2014, pp. 1-185.

25 Publicado en el BOCG, Congreso, X Legislatura, Serie A, n. ${ }^{\circ}$ 105-3, 24 de noviembre de 2014, pp. 1-29.

26 Cinco de las enmiendas presentadas por la oposición postulaban la supresión de esta última infracción por distintos motivos. Para unos, la práctica de juegos o de actividades deportivas en espacios públicos no habilitados para ello, cuando exista un riesgo de que se ocasionen daños a las personas o a los bienes, no 
una Disposición final primera sobre el régimen especial de Ceuta y Melilla, que analizaremos más adelante, con la siguiente redacción: Los extranjeros que sean detectados en la línea fronteriza de la demarcación territorial de Ceuta o Melilla mientras intentan superar, en grupo, los elementos de contención fronterizos para cruzar irregularmente la frontera podrán ser rechazados a fin de impedir su entrada ilegal en España ${ }^{27}$. Es la principal novedad, aunque es sólo una primera versión de la polémica disposición, que será reformulada en el Senado.

Una última consideración sobre el informe de la ponencia. En su favor hay que anotar el esfuerzo desplegado para dar una respuesta a las objeciones formuladas desde el punto de vista competencial por los grupos nacionalistas. Lo cierto es que éstos se dan por satisfechos con la aceptación de algunas de sus enmiendas ${ }^{28}$.

La Comisión de Interior del Congreso acordó aceptar como Dictamen el texto propuesto por la Ponencia y una vez debatido y aprobado dicho Dictamen por el Pleno en la sesión del 11 de noviembre de 2014, el proyecto siguió su tramitación en el Senado. En la Cámara Alta, se presentaron ocho propuestas de veto y 225 enmiendas al articulado ${ }^{29}$.

La Ponencia designada al efecto ${ }^{30}$, con el voto favorable de los ponentes del Grupo Popular, acordó proponer la incorporación al texto de las enmiendas 212 a 225 del citado Grupo, en sus propios términos, con la salvedad de la enmienda n. ${ }^{\circ} 224$, en relación con la Disposición Final Primera, cuya redacción se modifica ligeramente ${ }^{31}$. El objetivo de esta nueva versión de la Disposición, que será ya la definitiva, es, según los enmendantes (p. 144), el de hacer explícita la garantía del respeto a la normativa internacional en materia de derechos humanos y, más específicamente, a la que regula el derecho de asilo y la protección subsidiaria, de modo que quienes intenten la entrada ilegal en España puedan solicitar, en su caso, el reconocimiento de la condición de refugiado o la protección subsidiaria en los lugares habilitados al efecto en los puestos fronterizos. Bajo la presión de

afecta para nada a la seguridad ciudadana. Para otros, es un asunto propio de la esfera municipal y no tiene sentido que intervengan las autoridades estatales o autonómicas.

27 La enmienda se justifica por la necesidad de reflejar expresamente la singularidad geográfica de ambas ciudades, que constituyen las únicas fronteras terrestres de la Unión Europea en territorio africano.

28 En su intervención en el debate de totalidad, el portavoz del Grupo Vasco, E. Olabarría, exigió que se respetase la esfera de decisión de aquellas Comunidades Autónomas que tienen competencias plenas en materia de seguridad pública y cuentan con policías integrales. Parece que la ponencia tomó nota de esa reclamación, porque decidió aceptar dos importantes enmiendas presentadas por el citado Grupo. La primera en relación con los órganos competentes en materia sancionadora (art. 32) y la segunda para abrir la puerta a la creación por esas Comunidades de sus propios Registros de infracciones. Tanto los portavoces del Grupo Vasco como los del Grupo Catalán reconocen que se han atendido sus propuestas, aunque lamentan que no se haya recogido su pretensión de que las policías autonómicas pudieran acceder a las bases de datos de Interpol y Europol.

29 BOCG, Senado, X Legislatura, n. ${ }^{\circ} 469,13$ de febrero de 2015 , p. 25 y ss.

30 Vid. su Informe en el BOCG, Senado, X Legislatura, n. ${ }^{\circ} 480,2$ de marzo de 2015, p. 3 y ss.

31 Se prescinde del apartado 4 de la enmienda («El Ministerio del Interior aprobará un protocolo de actuación de las Fuerzas y Cuerpos de Seguridad del Estado en los perímetros fronterizos»). 
numerosas organizaciones y de la opinión pública, el Grupo Popular trata de maquillar con esa apelación a las normas internacionales la crudeza de la fórmula aprobada en el Congreso.

La Comisión de Interior, a la vista del Informe emitido por la Ponencia decidió aceptar como Dictamen texto propuesto por la misma. Y en la sesión celebrada el 12 de marzo el Pleno del Senado aprobó dicho Dictamen con leves retoques. Las enmiendas aprobadas por el Senado fueron sometidas a debate y votación en la sesión del Pleno del Congreso celebrada el 26 de marzo de 2015, siendo aprobadas con el voto favorable de los diputados del Grupo Popular ${ }^{32}$.

La LO 4/2015, de 30 de marzo, de protección de la seguridad ciudadana, fue publicada en el BOE del día 31 de marzo ${ }^{33}$. Dentro del plazo de tres meses previsto en el art. 33.1 LOTC, se presentaron dos recursos de inconstitucionalidad contra varios preceptos de la nueva LOPSC. El primero, fechado el 21 de mayo, promovido por más de 50 diputados de los grupos parlamentarios Socialista; La Izquierda Plural (IU/ICV-EUiA/CHA); UPyD; y Mixto (CC, Compromís-Q) del Congreso, que fue admitido a trámite por el Pleno del Tribunal Constitucional el 9 de junio de 2015. El segundo, promovido por el Parlamento de Cataluña, fue admitido a trámite el 27 de julio ${ }^{34}$.

Sin entrar a juzgar ahora la solidez de los motivos alegados por los recurrentes, lo que se constata a primera vista es un cierto desfase entre la contundencia con que se critica y condena la nueva regulación en el plano político y el reducido número de preceptos impugnados (8 en el caso del recurso formulado por los diputados de la oposición y 9 en el del Parlament ${ }^{35}$, sólo en parte coincidentes).

En todo caso, no cabe duda de que la conocida popularmente como Ley mordaza sigue provocando un fuerte rechazo en la opinión pública española ${ }^{36}$. Y sigue suscitando muchas reservas en las organizaciones internacionales especializadas en la defensa de los derechos humanos ${ }^{37}$.

32 Vid. DSCD, Pleno, Año 2015, X Leg., n. ${ }^{\circ}$ 269, 26 de marzo de 2015, pp. 53-67.

33 BOE n. ${ }^{\circ} 77$, de 31 de marzo de 2015, Sec. I. p. 27216 y ss.

34 El Pleno del Parlament decidió interponer el recurso en su sesión del 19 de junio, con los únicos votos en contra, 18, del PP. Lo hizo a propuesta de ERC e ICV-EUiA. Vid. Diari de Sessions del Parlament, Sèrie $P$, n. $^{\circ} 113,19$ de juny de 2015 , p. 11 y ss

35 Son precisamente los 9 artículos que el Consell de Garanties Estatutàries consideró contrarios a la Constitución o el Estatuto en un dictamen solicitado por los grupos ERC e ICV-EUiA, en el que descartó, en cambio, la inconstitucionalidad de otros preceptos sometidos a su consideración.

36 En una encuesta de Metroscopia publicada en el diario EL PAIS el 5 de julio de 2015, el $75 \%$ de los consultados (3 de cada 4) se mostró en contra de dicha ley.

37 Por mencionar sólo uno de los pronunciamientos más recientes, el Comité de Derechos Humanos de la ONU aprobó el 20 julio de 2015 unas Observaciones Finales sobre el sexto informe periódico presentado por España, que incluyen el siguiente apartado (n. $\left.{ }^{\circ} 25\right)$ sobre la Ley de Seguridad Ciudadana: «Preocupa al Comité el efecto disuasorio que pueda tener para la libertad de expresión, de asociación y de reunión pacífica la reciente aprobación de la Ley... En particular, le preocupa... el uso excesivo de sanciones administrativas contenidas en la Ley, las cuales excluyen la aplicación de ciertas garantías judiciales, establecidas en el Pacto; el uso de términos vagos y ambiguos en algunas disposiciones, lo que podría dar lugar a un amplio margen de discrecionalidad en la aplicación de dicha Ley; y la prohibición de hacer uso de imágenes o datos personales o 


\section{EL CONTENIDO DE LA LOPSC}

\section{Disposiciones generales (Capítulo I)}

En este primer capítulo se define el objeto de la ley partiendo de un concepto material de seguridad ciudadana entendida como actividad dirigida a la protección de personas y bienes y al mantenimiento de la tranquilidad de los ciudadanos. La seguridad ciudadana, se dice en el art. 1.1, es «un requisito indispensable para el pleno ejercicio de los derechos fundamentales y las libertades públicas». En el preámbulo, modificado tras la aprobación de dos enmiendas del Grupo Vasco en el Congreso, se matiza esa afirmación, al precisar que la seguridad ciudadana es «la garantía» de que tales derechos puedan ser ejercidos libremente por la ciudadanía. Y se inserta el siguiente párrafo: «Libertad y seguridad constituyen un binomio clave para el buen funcionamiento de una sociedad democrática avanzada, siendo la seguridad un instrumento al servicio de la garantía de derechos y libertades y no un fin en sí mismo ${ }^{38}$. Con esta puntualización se quiere salir al paso de las críticas formuladas por la oposición contra la concepción autoritaria del orden público que inspira la ley, no como presupuesto para el ejercicio de los derechos, sino como un derecho en sí mismo, como un bien jurídico autónomo protegible en sí mismo.

En el artículo 3 se enumeran los fines que deben perseguir los poderes públicos al actuar en este ámbito. Entre ellos, y en primer lugar, la protección del libre ejercicio de los derechos fundamentales y las libertades públicas y los demás derechos reconocidos y amparados por el ordenamiento jurídico; pero también la garantía del normal funcionamiento de las instituciones; la preservación de la seguridad y la convivencia ciudadanas; la protección de las personas y bienes, con especial atención a los menores y a las personas con discapacidad necesitadas de especial protección; la pacífica utilización de los espacios destinados al uso y disfrute público, la garantía de la normal prestación de los servicios básicos para la comunidad y la prevención de la comisión de delitos e infracciones administrativas directamente relacionadas con los fines indicados.

En el artículo 4 se enuncian «los principios rectores de la acción de los poderes públicos en relación con la seguridad ciudadana»: el ejercicio de las potestades y facultades reconocidas por esta Ley «se regirá por los principios de legalidad, igualdad de trato y no discriminación, oportunidad, proporcionali-

profesionales de autoridades o miembros de las Fuerzas y Cuerpos de Seguridad». El Comité concluye instando al Estado parte a revisar dicha Ley en consulta con todos los actores involucrados, con el fin de asegurar su estricta conformidad con el PIDCP (p. 8).

38 Por tanto, se dice a renglón seguido, cualquier limitación en el ejercicio de las libertades ciudadanas por razones de seguridad debe ampararse en los principios de legalidad y proporcionalidad, de manera que la injerencia en las mismas sea la estrictamente indispensable para garantizar la seguridad. 
dad, eficacia, eficiencia y responsabilidad, y se someterá al control administrativo y jurisdiccional» ${ }^{39}$.

Este capítulo se cierra con un precepto, el artículo 7, que regula el deber de colaboración de todas las autoridades y los funcionarios públicos ${ }^{40}$; de los distintos cuerpos policiales, de los ciudadanos ${ }^{41} \mathrm{y}$ de las empresas y el personal de seguridad privada ${ }^{42}$, de acuerdo con una perspectiva integral de la seguridad pública.

\section{Documentación e identificación personal (Capítulo II)}

En el segundo capítulo se regula con mayor extensión que en la LO 1/1992 la acreditación de la identidad de los ciudadanos españoles, el valor probatorio del Documento Nacional de Identidad (DNI) y del pasaporte y los deberes de los titulares de estos documentos. En relación con el DNI, se establece la obligación no sólo de exhibirlo, sino también de permitir su comprobación a requerimiento de los agentes de la autoridad, con el fin de que éstos puedan verificar su autenticidad. Esto último es una novedad, que se introduce para impedir que la persona requerida pueda negarse a facilitarlo alegando que el documento es personal e intransferible ${ }^{43}$, como venía sucediendo en no pocas ocasiones. Otra novedad es el deber de notificar su pérdida o extravío que impone a su titular el artículo 9 en su inciso final: «De su sustracción o extravío deberá darse cuenta tan pronto como sea posible a la comisaría de Policía o puesto de las Fuerzas y Cuerpos de Seguri-

39 Este elenco de principios se completa con una declaración introducida en el Senado, a iniciativa del propio Grupo Popular (enmienda n. ${ }^{\circ} 213$ ), para remarcar la primacía de los derechos: «En particular, las disposiciones de los capítulos III y $\mathrm{V}$ deberán interpretarse y aplicarse del modo más favorable a la plena efectividad de los derechos fundamentales y libertades públicas, singularmente de los derechos de reunión y manifestación, las libertades de expresión e información, la libertad sindical y el derecho de huelga».

40 Todas las autoridades y funcionarios públicos deberán colaborar con las autoridades y órganos competentes en materia de seguridad ciudadana y prestarles el auxilio que sea posible y adecuado. En particular, «cuando, por razón de su cargo, tengan conocimiento de hechos que perturben gravemente la seguridad ciudadana o de los que racionalmente pueda inferirse que pueden producir una perturbación grave, estarán obligados a ponerlo inmediatamente en conocimiento de la autoridad competente».

41 «Las autoridades y órganos competentes y los miembros de las Fuerzas y Cuerpos de Seguridad podrán recabar de los particulares su ayuda y colaboración en la medida necesaria para el cumplimiento de los fines previstos en esta Ley, especialmente en los casos de grave calamidad pública o catástrofe extraordinaria, siempre que ello no implique riesgo personal para los mismos. Quienes sufran daños y perjuicios por estas causas serán indemnizados de acuerdo con las leyes».

42 «Las empresas de seguridad privada, los despachos de detectives privados y el personal de seguridad privada tienen un especial deber de auxiliar a las Fuerzas y Cuerpos de Seguridad en el ejercicio de sus funciones, prestarles la colaboración que precisen y seguir sus instrucciones, en los términos previstos en la normativa de seguridad privada».

43 Dicho documento es, en efecto, «personal e intransferible, debiendo su titular mantenerlo en vigor y conservarlo y custodiarlo con la debida diligencia. No podrá ser privado del mismo, ni siquiera temporalmente, sino en los supuestos en que, conforme a lo previsto por la ley, haya de ser sustituido por otro documento» (art. 9.1). 
dad más próximo». Ambas obligaciones se extienden a los titulares de un pasaporte español (art. 11).

\section{Actuaciones para el mantenimiento y restablecimiento de la seguridad ciudadana (Capítulo III)}

La sección 1. ${ }^{a}$ (Potestades generales de policía de seguridad) contiene una regulación más detallada de las potestades de intervención policial. Se habilita a las autoridades competentes para ordenar distintas actuaciones dirigidas al mantenimiento y, en su caso, al restablecimiento de la tranquilidad ciudadana, de conformidad con los presupuestos y requisitos establecidos para cada una de esas diligencias. Con carácter general, las actuaciones policiales acordadas por dichas autoridades habrán de ser las «estrictamente necesarias para asegurar la consecución de los fines previstos en esta Ley, mediante resolución debidamente motivada» (art. 14). De acuerdo, por tanto, con los principios de proporcionalidad e injerencia mínima, como recuerda el preámbulo.

Para la oposición, en cambio, el articulado de la ley no responde a esos principios. A su juicio, se autoriza la intervención policial ante la mera sospecha, ante cualquier riesgo. Y se amplían «los apoderamientos especiales y genéricos» a las fuerzas y cuerpos de seguridad para actuar discrecionalmente cuando lo estiman pertinente. Lo que conduce, a su vez, al apoderamiento del espacio público por parte de la Administración. Deja de ser un espacio de interacción entre los ciudadanos para pasar a ser un ámbito en el que los ciudadanos solo pueden hacer lo que la ley les autoriza ${ }^{44}$. A pesar de esta impugnación global de la filosofía que la preside, esta sección, con la salvedad del controvertido artículo 20, es seguramente la que merece una valoración más positiva. Y así lo reconocen expresamente algunos de sus más acerados críticos ${ }^{45}$.

a) La entrada y registro en domicilio y edificios de organismos oficiales (art. 15)

En este punto, no se registra ninguna novedad respecto de la regulación anterior (el célebre artículo 21 de la Ley de 1992, el de «la patada en la puerta»). En su primer apartado, el artículo 15 se remite a lo dispuesto en la Constitución y las leyes, para añadir en el siguiente apartado que «será causa legítima suficiente para la entrada en domicilio la necesidad de evitar daños inminentes y graves a las personas y a las cosas, en supuestos de catástrofe, calamidad, ruina inminente u otros semejantes de extrema y urgente necesidad».

44 E. Olabarría, DSCD, cit., pp. 33-34.

45 Vid. por ejemplo, la intervención del portavoz de la Izquierda Plural, el diputado Sixto Iglesias, en debate de totalidad (DSCD, cit., p. 38). 


\section{b) La diligencia de identificación de personas (art. 16)}

En su redacción final, este precepto regula la diligencia de identificación de una forma más precisa y garantista que el artículo 20 de la LO 1/1992. Pero para ello hubo que depurar en bastantes aspectos el texto inicial ${ }^{46}$. El artículo 16.1 del Anteproyecto habilitaba a los agentes de las Fuerzas y Cuerpos de Seguridad para requerir la identificación de las personas y realizar las comprobaciones necesarias «para el cumplimiento de las funciones de seguridad ciudadana, prevención delictiva y de infracciones administrativas». Como recuerda el informe del CGPJ, en el artículo 20 de la LOPSC de 1992 la identificación de los ciudadanos y, en su caso, la subsiguiente privación de libertad de los indocumentados se enmarca en el ejercicio de las funciones de indagación y prevención propias de las FCSE, que el artículo 11 de la LOFCS circunscribe a los actos delictivos («para impedir la comisión de un delito o falta»). En la misma línea, la STC 341/1993, de 18 de noviembre, que resolvió los recursos y cuestiones de inconstitucionalidad promovidas frente a determinados preceptos de la LOPSC, dejó bien claro que «la privación de libertad con fines de identificación sólo podrá afectar a personas no identificadas de las que razonable y fundadamente pueda presumirse que se hallan en disposición actual de cometer un ilícito penal... o a aquellas, igualmente no identificables, que hayan incurrido ya en una infracción administrativa». No puede justificarse, por tanto, una limitación tan severa de la libertad personal para prevenir infracciones administrativas. EL Gobierno rectifica y en el Proyecto ya sólo se hace referencia a la prevención de infracciones penales. Y así figura en la Ley aprobada («En el cumplimiento de sus funciones de indagación y prevención delictiva, así como para la sanción de infracciones penales y administrativas... $)^{47}$. En estos supuestos, se añade a continuación, «los agentes podrán realizar las comprobaciones necesarias..., incluida la identificación de las personas cuyo rostro no sea visible total o parcialmente por utilizar cualquier tipo de prenda u objeto que lo cubra, impidiendo o dificultando la identificación, cuando fuere preciso a los efectos indicados» ${ }^{48}$.

46 Texto severamente criticado en su momento por M. Presno: «nos encontramos aquí con una versión, corregida y empeorada, del vigente artículo 20 LOSC», que no tiene en cuenta los matices introducidos en la doctrina de la STC 341/1993 (op. cit., p. 290).

47 Por las mismas razones se modificó también el apartado b) de ese precepto, que describe uno de los supuestos en los que una persona podrá ser requerida para su identificación, para sustituir la expresión "prevenir la comisión de una infracción» por «prevenir la comisión de un delito». Y el artículo 17.2 del Anteproyecto, que contemplaba la posibilidad de establecer controles en las vías, lugares o establecimientos públicos con el fin de prevenir o descubrir a los autores de cualquier infracción. En el Proyecto (y finalmente en la Ley) sólo cabe esta actuación "para la prevención de delitos de especial gravedad o generadores de alarma social».

48 Para el CGPJ, la referencia expresa a la identificación de las personas que lleven el rostro embozado es superflua, porque, en todo caso, no podrá practicarse por el solo hecho de ir embozado, sino cuando concurra uno de los supuestos previstos en ese precepto, por lo que recomienda su supresión. No opina lo mismo el Consejo de Estado, que sostiene en su dictamen que «resulta adecuado — y así lo avala la práctica comparada de las democracias de nuestro entorno- que, una vez comprobada la razonable necesidad de identificación, se exija descubrir el rostro de quienes utilicen, con uno u otro nombre, antifaces» (Dictamen 557/2014, p. 16). 
Otra novedad que merece un juicio positivo es la declaración contenida en el último párrafo del art. 16.1: «En la práctica de la identificación se respetarán estrictamente los principios de proporcionalidad, igualdad de trato y no discriminación por razón de nacimiento, nacionalidad, origen racial o étnico, sexo, religión o creencias, edad, discapacidad, orientación o identidad sexual, opinión o cualquier otra condición o circunstancia personal o social». Destaca por sus implicaciones prácticas la referencia a la nacionalidad y al origen racial o étnico como motivos de discriminación expresamente prohibidos. En su discurso de presentación, el ministro del Interior presumió de que por primera vez una norma con rango de ley prohibía las identificaciones indiscriminadas y las basadas en perfiles étnicos. Se da respuesta así a una demanda formulada por numerosos organismos, que consideraban insuficiente la prohibición de este tipo de redadas en la Circular 2/2012 de la Dirección General de la Policía ${ }^{49}$.

En los siguientes apartados de este precepto, se regula una figura ya prevista en el artículo 20 de la Ley anterior, la denominada retención, un supuesto de limitación de la libertad personal que, como es sabido, no reviste los caracteres de la detención ${ }^{50}$. Se describe en términos muy similares: «cuando no fuera posible la identificación por cualquier medio, incluida la vía telemática o telefónica, o si la persona se negase a identificarse, los agentes, para impedir la comisión de un delito o al objeto de sancionar una infracción, podrán requerir a quienes no pudieran ser identificados a que les acompañen a las dependencias policiales más próximas en las que se disponga de los medios adecuados para la práctica de esta diligencia, a los solos efectos de su identificación y por el tiempo estrictamente necesario...». Pero la Ley recién aprobada rodea esa operación de traslado a dependencias policiales de más garantías.

En primer lugar, la exigencia de que no se prolongue más allá del tiempo estrictamente indispensable se concreta en el sentido de que nunca podrá ser superior a las seis horas. Se fija pues un plazo temporal para la identificación del indocumentado que es trasladado a las dependencias policiales más próximas. El Anteproyecto no incluía ese límite temporal, pero en su Dictamen el Consejo de Estado, haciéndose eco de la recomendación formulada en la STC 341/1993 (de-

49 DSCD, cit., p. 24. Para algunos representantes de la oposición, tendría que haberse dado un paso más para concretar ese mandato de no discriminación y haber prohibido expresamente el uso de perfiles étni$\cos$, porque es una práctica generalizada en nuestro país. Con el fin de prevenir este tipo de abusos policiales, se reclama también la adopción de otras medidas para documentar las identificaciones y la creación de un mecanismo independiente de supervisión que tramite y resuelva las posibles quejas. Durante muchos años esta práctica ha sido denunciada por todas las instituciones y organizaciones que se han ocupado de testar el estado de salud de nuestras libertades, pero sigue siendo, me temo, una asignatura pendiente. En las Observaciones antes citadas, aprobadas en julio de 2015, el Comité de Derechos Humanos expresa su preocupación porque «persiste la práctica de controles policiales basados en perfiles raciales y étnicos contra ciertas minorías étnicas, en particular los romaníes».

50 Conviene recordar que, en su sentencia 341/1993, el Tribunal Constitucional avaló expresamente la constitucionalidad de esta medida, siempre que se practicase por el tiempo indispensable. 
bería indicarse la duración máxima tanto de la retención como de la medida de identificación en dependencias policiales), consideró que la referencia al tiempo estrictamente necesario «debería completarse con la determinación de un límite horario máximo expreso. Dicho límite pudiere fijarse en seis horas, período en el que, hoy y habida cuenta de los medios con que se cuenta, se pueden realizar con holgura las operaciones de identificación» (p. 17). Esta observación, que no se califica de esencial, pero se considera fundamental para salvaguardar la constitucionalidad del texto sometido a consulta, fue debidamente atendida, añadiéndose en el párrafo primero del artículo 16.2 el inciso «que en ningún caso podrá superar las seis horas». Y en esos términos se recoge en la Ley.

El Dictamen del Consejo de Estado está también en el origen de otra importante mejora en la regulación de esta diligencia. Considera el Consejo que, «al retenido y desplazado a las dependencias policiales para su identificación, o en su caso cacheo, debería proporcionársele el correspondiente volante documental en el que figuren con exactitud los momentos inicial y final de la retención, la identificación del agente o agentes que adoptaron la retención y las circunstancias que han justificado la adopción de la medida» (p. 17). Esta sugerencia se recoge, en términos muy parecidos, en el artículo 16.4 de la Ley: «A las personas desplazadas a dependencias policiales a efectos de identificación, se les deberá expedir a su salida un volante acreditativo del tiempo de permanencia en ellas, la causa y la identidad de los agentes actuantes $»^{51}$.

Otra garantía adicional no contemplada en la LOPSC de 1992 es la obligación de informar al ciudadano de forma inmediata y comprensible de las razones de la retención. Siguiendo de nuevo la recomendación del CGPJ, se incluye en el Proyecto la obligación de los agentes de informar, de modo inmediato y comprensible, a la persona a la que soliciten su identificación de las razones del requerimiento, de acuerdo con la inequívoca declaración contenida en la STC 341/1993 (FJ 6): «el requerido a acompañar a la fuerza pública debe ser informado, de modo inmediato y comprensible, de las razones de tal requerimiento».

\section{c) La restricción del tránsito y controles en las vías públicas (art. 17)}

Se habilita a los agentes de las Fuerzas y Cuerpos de Seguridad para «limitar o restringir la circulación o permanencia en vías o lugares públicos y establecer zonas de seguridad en supuestos de alteración de la seguridad ciudadana o de la pacífica

51 En las dependencias policiales «se llevará un libro-registro en el que sólo se practicarán asientos relacionados con la seguridad ciudadana. Constarán en él las diligencias de identificación practicadas, así como los motivos, circunstancias y duración de las mismas, y sólo podrán ser comunicados sus datos a la autoridad judicial competente y al Ministerio Fiscal. El órgano competente de la Administración remitirá mensualmente al Ministerio Fiscal extracto de las diligencias de identificación con expresión del tiempo utilizado en cada una. Los asientos de este libro-registro se cancelarán de oficio a los tres años» (art. 16.3). 
convivencia, o cuando existan indicios racionales de que pueda producirse dicha alteración, por el tiempo imprescindible para su mantenimiento o restablecimiento ${ }^{52}$. Estas medidas, en la medida en que limitan el tránsito en la vía pública, afectan sin duda a la libertad deambulatoria, al derecho fundamental a la libre circulación (art. 19.1 CE), y requieren por tanto una habilitación legal apropiada ${ }^{53}$.

\section{d) Las comprobaciones y registros en lugares públicos (art. 18)}

Este precepto permite a los agentes de la autoridad realizar «las comprobaciones en las personas, bienes y vehículos que sean necesarias para impedir que en las vías, lugares y establecimientos públicos se porten o utilicen ilegalmente armas, explosivos, sustancias peligrosas u otros objetos, instrumentos o medios que generen un riesgo potencialmente grave para las personas, susceptibles de ser utilizados para la comisión de un delito o alterar la seguridad ciudadana, cuando tengan indicios de su eventual presencia en dichos lugares, procediendo, en su caso, a su intervención» ${ }^{54}$.

En el dictamen antes citado, el Consell de Garanties Estatutàries, considera que este precepto no es contrario al artículo 18.1 CE. Los registros y comprobaciones de vehículos y efectos personales constituyen una injerencia en el ámbito protegido por el derecho a la intimidad. Pero esta restricción está justificada porque persigue una finalidad constitucionalmente legítima (la protección de la seguridad de las personas y de los bienes y la prevención de delitos) y delimita con bastante claridad y precisión los supuestos en los que la policía puede realizar

52 También «podrán ocupar preventivamente los efectos o instrumentos susceptibles de ser utilizados para acciones ilegales». Tanto este inciso, como el apartado 2 ( «Para la prevención de delitos de especial gravedad o generadores de alarma social, así como para el descubrimiento y detención de quienes hubieran participado en su comisión y proceder a la recogida de los instrumentos, efectos o pruebas, se podrán establecer controles en las vías, lugares o establecimientos públicos, siempre que resulte indispensable proceder a la identificación de personas que se encuentren en ellos, al registro de vehículos o al control superficial de efectos personales») son fiel reproducción de lo dispuesto en la Ley anterior.

53 Es verdad que en el artículo 19 de la Ley de 1992 esta medida sólo se permitía en los supuestos de efectiva alteración del orden o la pacífica convivencia, y ahora puede adoptarse también cuando haya indicios racionales de que pueda producirse esa alteración, con lo que se amplía su ámbito de aplicación y se deja un cierto margen de apreciación discrecional a la policía. Pero esta objeción ha sido examinada por el Consell de Garanties Estatutàries de Catalunya en su Dictamen 7/2015, de 4 de junio, sobre la LOPSC, llegando a la conclusión de que «la expresión «indicios racionales» acota suficientemente la habilitación a la policía, porque los «indicios» para poder justificar la adecuación de dichas actuaciones deben reunir principalmente dos requisitos: deben ser accesibles para terceros y deben proporcionar una base real de la que se pueda inferir que se ha perpetrado un delito o que se perpetrará. Por lo tanto, no pueden basarse en valoraciones globales de la persona o en circunstancias anímicas ni en meras hipótesis subjetivas, sino que consisten en buenas razones o fuertes presunciones de que las infracciones están a punto de cometerse». Son, en consecuencia, restricciones «razonables, proporcionadas a la finalidad y a la protección de otros bienes» (pp. 28-30).

54 Los agentes podrán proceder asimismo a «la ocupación temporal de cualesquiera objetos, instrumentos o medios de agresión, incluso de las armas que se porten con licencia, permiso o autorización si se estima necesario, con objeto de prevenir la comisión de cualquier delito, o cuando exista peligro para la seguridad de las personas o de los bienes». 
esas comprobaciones. Las medidas previstas resultan no solo adecuadas para alcanzar el mencionado objetivo sino también necesarias, al no apreciarse de manera patente que existan otras medidas alternativas igualmente idóneas y menos restrictivas del derecho a la intimidad personal. Además, vista la importancia de los bienes protegidos y dado que la afectación del citado derecho no presenta un nivel de intensidad especialmente grave, se puede considerar que se respeta el principio de proporcionalidad en sentido estricto (pp. 31-37).

En el artículo 19 se recogen las disposiciones comunes a las diligencias de identificación, registro y comprobación. Estas diligencias no estarán sujetas a las mismas formalidades que la detención. Las garantías propias de la detención consistentes en el derecho a no declarar y a la asistencia de abogado (art. 17.3 CE), no son trasladables a estos supuestos previstos en la LOPSC ${ }^{55}$.

\section{e) Los registros corporales externos (art. 20)}

Se regulan por primera vez los registros corporales externos y superficiales, comúnmente conocidos como cacheos, y se establecen los requisitos y garantías para su práctica ${ }^{56}$. Sólo podrán realizarse cuando existan indicios racionales para suponer que pueden conducir al hallazgo de instrumentos, efectos u otros objetos relevantes para el ejercicio de las funciones de indagación y prevención que encomiendan las leyes a las Fuerzas y Cuerpos de Seguridad.

Salvo que exista «una situación de urgencia por riesgo grave e inminente para los agentes», el registro «se realizará por un agente del mismo sexo que la persona sobre la que se practique esta diligencia»y «si exigiera dejar a la vista partes del cuerpo normalmente cubiertas por ropa, se efectuará en un lugar reservado y fuera de la vista de terceros ${ }^{57}$. Estos registros deberán respetar los principios de proporcionalidad, igualdad de trato y no discriminación, así como el de

55 El senador Iglesias (IU) formuló una enmienda a este precepto con la finalidad de que estas diligencias sí estuviesen sujetas a las mismas formalidades que las detenciones y se contase en las mismas con un intérprete cuando resultase necesaria su presencia (DSS, cit., p. 14090).

56 La regulación expresa de la diligencia de cacheo merece una valoración positiva por parte del CGPJ en su informe («es innegable que la actual regulación resulta insuficiente»). Más aún, «algunos autores vienen denunciando la falta de cobertura legal», ya que las únicas disposiciones específicas sobre los cacheos se encuentran en el ámbito penitenciario y aduanero. Pero el CGPJ advierte que la regulación prevista en el anteproyecto es incompleta e imprecisa. No define el cacheo, tampoco lo limita al registro externo y superficial y falta, además, toda referencia a la manera de llevarse a cabo el cacheo. A su juicio, debería indicarse de modo expreso el respeto a la dignidad e intimidad de la persona sometida al mismo y su carácter reservado, buscando siempre el lugar más idóneo y discreto posible. Del mismo modo, debería recogerse la obligación de que se practique por persona del mismo sexo que la cacheada. Se recomienda, por todo ello, la revisión del precepto. Pues bien, siguiendo las pautas marcadas en ese informe, la diligencia de cacheo se regula en el artículo 20 del Proyecto con más precisión y mayores garantías.

57 Se dejará constancia escrita de esta diligencia, de sus causas y de la identidad del agente que la adoptó. Este último inciso se añadió tras la aprobación de una enmienda del Grupo Vasco, que se inspiraba a su vez en una recomendación contenida en el dictamen del Consejo de Estado. 
injerencia mínima, y se realizarán del modo que causen el menor perjuicio a la intimidad y dignidad de la persona afectada, que será informada de modo inmediato y comprensible de las razones de su realización

Pese a todas estas cautelas y la tácita anuencia de la oposición parlamentaria, que nunca tuvo este artículo en su punto de mira, el Consell de Garanties Estatutàries declaró, en una conclusión adoptada por unanimidad, que este precepto es contrario al artículo 18.1 CE. Recuerda en su dictamen que con el fin de no lesionar el derecho a la intimidad (o a la vida privada) la jurisprudencia del Tribunal Constitucional y del TEDH viene exigiendo que los registros corporales estén previstos en una norma con rango de ley suficientemente clara y precisa, persigan una finalidad legítima y respeten el principio de proporcionalidad. Pues bien, el precepto examinado no se ajusta, en su opinión, a esta doctrina jurisprudencial porque «la definición de la finalidad que se pretende alcanzar con su aplicación es imprecisa, en la medida en que permite una actuación excesivamente discrecional de los agentes de la autoridad, basada en meras suposiciones personales y subjetivas». Además, «esta actuación se puede dirigir al hallazgo de una categoría amplísima de objetos, que no se especifican ni por su naturaleza, ni por su peligrosidad». Por otra parte, el precepto carece de los elementos que la jurisprudencia constitucional exige para delimitar este tipo de intervenciones, como por ejemplo que sean excepcionales o que se puedan llevar a cabo de forma individualizada, según las circunstancias de cada caso. Y, por último, ambos apartados 1 y 2 presentan una total indeterminación respecto de una cuestión tan capital como cuál es el grado de afectación sobre la intimidad personal que permiten los registros corporales que se regulan y que, aunque se califiquen de externos y superficiales, pueden comportar un desnudo parcial de la persona (pp. 37-47).

Por motivos análogos, este precepto, más concretamente su apartado 2, fue impugnado también en el recurso presentado por los diputados de la oposición en el Congreso (p. 5 y ss). A su juicio, vulnera los artículos 10.1, 15 y 18 CE al permitir el registro, que puede consistir incluso en un desnudo total o parcial, sin establecer los requisitos y garantías exigidos por la Constitución y plasmados en la doctrina del Tribunal Constitucional, que ha insistido en que han de ser proporcionados al fin que se persigue y en ningún caso arbitrarios ni inmotivados, porque está en juego el derecho a la intimidad corporal que garantiza un ámbito de inmunidad frente a toda indagación o pesquisa que sobre el propio cuerpo quisiera imponerse contra la voluntad de la persona ${ }^{58}$. Además, el registro corpo-

58 Si se analiza el conflicto potencial entre la garantía de la seguridad ciudadana, de un lado, y la intromisión en la intimidad corporal del sometido a registro, de otro, se aprecia la desproporción, pues resulta evidente que, tal y como está regulado, el registro no es una medida necesaria para mantener el orden y la seguridad. Sin embargo, se permite, por primera vez en nuestro ordenamiento, sin que se exija la concurrencia de razones de urgencia y necesidad y de los requisitos de proporcionalidad y razonabilidad. Los recurrentes invocan la doctrina establecida en la STC 218/2002, en relación con el registro de las personas recluidas en centros penitenciarios. Es indudable, se lee en su FJ 4, que «una medida de registro personal de los reclusos mediante el cacheo con 
ral se contempla con carácter general. Hasta ahora, explican los recurrentes, este tipo de registros corporales aparece regulado en nuestro ordenamiento en relación con personas privadas de libertad. Y, en todo caso, se ha de acreditar su necesidad y proporcionalidad respecto del fin perseguido (la seguridad del centro). En cambio, el precepto impugnado permite, en el ámbito de las relaciones generales entre los ciudadanos y las Fuerzas de Seguridad del Estado, llevar a cabo este tipo de registros corporales, sin justificación alguna en el fin perseguido (seguridad ciudadana). En un terreno muy delicado, muy sensible, creo que la jurisprudencia constitucional proporciona razones sólidas para la impugnación ${ }^{59}$.

Bien distinta es la posición mantenida en su momento por el Consejo de Estado, que con apoyo en la doctrina sintetizada en la STC 171/2013, afirmaba en su dictamen que «el registro, incluso con desnudo integral y, a fortiori, el registro corporal externo, puede ser procedente por motivos de seguridad», siempre que la medida sea motivada y proporcional. Y añadía que «el registro corporal externo, hecho en la propia calle por agentes policiales o guardias civiles, es práctica tan usual como ineludible en la lucha cotidiana contra el tráfico de drogas y la pequeña delincuencia habitual».

\section{f) El mantenimiento y restablecimiento de la seguridad ciudadana en reuniones $y$ manifestaciones (art. 23)}

La redacción de este precepto en el Anteproyecto (art. 22) fue revisada a fondo a la vista de las consideraciones emitidas por el CGPJ y el Consejo Fiscal. Para empezar, se recupera en el artículo 23.1 del Proyecto la fórmula prevista en el artículo 16.1 de la LOPSC de 1992, que establecía la obligación de las autoridades de adop-

desnudo integral puede constituir, en determinadas situaciones, un medio necesario para la protección de la seguridad y el orden de un establecimiento penitenciario, si bien para afirmar la conformidad de la medida enjuiciada con la garantía constitucional a la intimidad personal de los reclusos es necesario ponderar, adecuadamente y de forma equilibrada, de una parte, la gravedad de la intromisión que comporta en la intimidad personal y, de otra parte, si la medida es imprescindible para asegurar la defensa del interés público que se pretende proteger. $\mathrm{Y}$ es claro que el respeto a esta exigencia requiere una fundamentación de la medida por parte de la Administración penitenciaria, asentada en razones individuales y contrastadas...». En ese caso, faltaba «toda mención de los motivos de seguridad concretos y específicos que determinaron la necesidad del cacheo integral, puesto que únicamente se hace una referencia genérica a sospechas de ocultación de algún objeto». Se cita asimismo la reciente STS (Sala 3. ${ }^{a}$ ) de 10 de febrero de 2015, que anuló el artículo 55.2 del RD 162/2014, de 14 de marzo, por el que se aprueba el Reglamento de funcionamiento y régimen interior de los Centros de Internamiento de Extranjeros, al considerar que el precepto se formula de manera no respetuosa con los derechos fundamentales del interno, «al permitir que puedan acordarse registros de internos sin necesidad de que existan sospechas racionales de su justificación sobre las concretas personas afectadas».

59 En su Recomendación sobre la LOPSC, fechada el 29 de junio de 2015, la Defensora del Pueblo, que decidió finalmente no interponer un recurso de inconstitucionalidad, como le habían pedido diversas organizaciones, instó al Ministerio del Interior a «elaborar con carácter urgente instrucciones para la práctica de los registros corporales externos», que incluyan «la obligatoria remisión inmediata al Juzgado competente y a la Fiscalía de la diligencia de registro corporal externo». 
tar las medidas necesarias para proteger la celebración de reuniones o manifestaciones impidiendo que se perturbe la seguridad ciudadana. Es verdad que una disposición similar ya está recogida en el artículo 3.2 de la LODR de 1983, pero parece razonable mantener esa indicación «en cuanto significativa del criterio o línea que ha de orientar esta materia» ${ }^{60}$. Se suprime, en cambio, en el Proyecto la previsión contenida en el 22.3 del Anteproyecto que permitía disolver una manifestación sin previo aviso no sólo en caso de alteraciones de la seguridad ciudadana con armas o con otros medios de acción violenta, sino también cuando «exista riesgo» de que se produzcan esas alteraciones. Esta ampliación de los supuestos de disolución de las reuniones y manifestaciones suponía una modificación de facto del artículo 5 LODR, que no contempla esa posibilidad. E implicaba también dejar en manos de los agentes de las FCSE una decisión de tanta trascendencia, confiando en su buen juicio a la hora de valorar el posible «riesgo» ${ }^{61}$.

La nueva regulación incorpora, como novedad, la exigencia de que esas medidas de intervención policial sean «graduales y proporcionadas a las circunstancias», de modo que la disolución de reuniones y manifestaciones sea «el último recurso» (art. 23.2), de acuerdo con la doctrina del Tribunal Constitucional.

Los portavoces parlamentarios de La Izquierda Plural echaron menos que no se contemplase en la ley la obligación —que sí se recoge en otros textos legalesde que los policías porten siempre su placa de identificación ${ }^{62}$. Una petición reiterada por el Defensor del Pueblo (en su informe de 2012, por ejemplo), que recomienda además que aumente el tamaño de los distintivos de identificación y que estos se sitúen en varios lugares del uniforme para que puedan verse desde distintas perspectivas ${ }^{63}$.

60 Informe del CGPJ, p. 40.

61 Vid. el Informe del CGPJ, p. 42. Se mantiene pues la fórmula del art. 16.2 de la Ley de 1992: las autoridades podrán acordar la disolución de reuniones y manifestaciones en lugares de tránsito público en los supuestos previstos en el artículo 5 de la LODR. Y podrán disolver también las concentraciones de vehículos en las vías públicas y retirar todo tipo de obstáculos cuando impidieran, pusieran en peligro o dificultaran la circulación por dichas vías. Tampoco hay novedades reseñables en el apartado 3: antes de intervenir, la policía deberán avisar a las personas afectadas, salvo que se produzca una alteración de la seguridad ciudadana con armas, artefactos explosivos u objetos contundentes o de cualquier otro modo peligrosos, en cuyo caso las Fuerzas y Cuerpos de Seguridad podrán disolver la reunión o manifestación o retirar los vehículos y obstáculos sin necesidad de previo aviso.

62 Vid. la intervención del diputado Sixto en el DSCD, cit., p. 39. Su compañero, el senador Iglesias, presentó una enmienda proponiendo la supresión del artículo 23 por restringir los derechos de huelga y manifestación. Y subsidiariamente, otras dos enmiendas alternativas: una, para consagrar el principio de que si en una manifestación se producen actos violentos aislados, no se proceda a la disolución del conjunto de la concentración, sino que se actúe sobre los violentos; y otra, pidiendo que se diese tiempo suficiente para que los concentrados pudieran comprender las órdenes o instrucciones policiales y actuar en consonancia (DSS, cit., pp. 14090-14091).

63 Advierte en el citado Informe que a pesar de la utilidad de las fotos y de los vídeos colgados en internet para valorar las actuaciones policiales, las imágenes obtenidas pueden ser insuficientes para la identificación de los responsables de dichas actuaciones a causa del reducido tamaño del distintivo de identificación personal. Cuando no resulta posible esa identificación a pesar de existir imágenes que reflejan con suficiente claridad la actuación policial y numerosos testigos de los hechos, se dejan impunes conductas irregulares e inaceptables, y se produce un deterioro de la imagen y el prestigio de los cuerpos policiales. 


\section{Potestades especiales de policía administrativa de seguridad (Capítulo IV)}

En este capítulo se regulan las medidas de control administrativo que el Estado puede ejercer sobre diferentes actividades relevantes para la seguridad ciudadana (establecimientos e instalaciones industriales, comerciales y de servicios, infraestructuras críticas y todo lo relativo a armas, explosivos, cartuchería y artículos pirotécnicos). Así, en virtud de lo dispuesto en el artículo 25, quienes ejerzan actividades como las de hospedaje, transporte de personas, acceso comercial a servicios telefónicos o telemáticos de uso público mediante establecimientos abiertos al público, comercio o reparación de objetos usados, alquiler o desguace de vehículos de motor, compraventa de joyas y metales, objetos u obras de arte, la cerrajería de seguridad o el comercio al por mayor de chatarra o productos de desecho, quedarán sujetas a las obligaciones de registro documental e información en los términos que establezcan las disposiciones aplicables. Por otro lado, se regula, desde la perspectiva de la seguridad ciudadana, la intervención de las autoridades en materia de espectáculos públicos y actividades recreativas, sin perjuicio de las competencias de las Comunidades Autónomas y de las entidades locales en lo que se refiere a su normal desarrollo.

\section{Régimen sancionador (Capítulo V)}

Este capítulo, el más extenso de la Ley, ha sufrido una profunda revisión respecto de la regulación contenida en el capítulo IV de la LOPSC de 1992. Esta actualización se justifica por la necesidad de tipificar con la precisión que exige el principio de legalidad las conductas sancionables. Con el transcurso del tiempo, se dice, han aparecido nuevas conductas reprochables que la Ley anterior no contemplaba o tienen que subsumirse en tipos infractores excesivamente genéricos. Por otra parte, desaparecen del Código Penal las faltas, lo que obliga a llevar al ámbito administrativo sancionador las faltas contra el orden público. Podemos destacar, entre las novedades más relevantes, la tipificación de determinadas infracciones como infracciones muy graves, la fijación de una serie de reglas para la gradación de las sanciones, la previsión de medidas provisionales anteriores a la imposición de las mismas, la creación de un Registro Central de Infracciones o la existencia de un procedimiento abreviado

a) Sujetos responsables, órganos competentes y reglas generales sobre las infracciones y la aplicación de las sanciones (Sección 1.9)

Se establece en el artículo 30 el principio general de que «la responsabilidad por las infracciones cometidas recaerá directamente en el autor del hecho en que consista la infracción». Y recogiendo una constante y reiterada sugerencia del 
Defensor del Pueblo, se consagra por primera vez la exención de responsabilidad de los menores de catorce años, en consonancia con la legislación sobre responsabilidad penal del menor. En el caso de que la infracción sea cometida por un menor de catorce años, la autoridad competente lo pondrá en conocimiento del Ministerio Fiscal para que inicie, en su caso, las actuaciones oportunas ${ }^{64}$.

En su apartado 3, el artículo 30 sienta el siguiente criterio: «A los efectos de esta Ley se considerarán organizadores o promotores de las reuniones en lugares de tránsito público o manifestaciones las personas físicas o jurídicas que hayan suscrito la preceptiva comunicación. Asimismo, aun no habiendo suscrito o presentado la comunicación, también se considerarán organizadores o promotores quienes de hecho las presidan, dirijan o ejerzan actos semejantes, o quienes por publicaciones o declaraciones de convocatoria de las mismas, por las manifestaciones orales o escritas que en ellas se difundan, por los lemas, banderas u otros signos que ostenten o por cualesquiera otros hechos pueda determinarse razonablemente que son directores ${ }^{65}$ de aquellas».

Esta imputación de responsabilidad a los organizadores o promotores por los hechos que pudieran producirse en el curso de una manifestación suscita serias reservas. En primer lugar, cuesta aceptar la asimilación o equiparación a estos efectos entre quienes suscriben la comunicación y quienes de algún modo pueden tener un papel de cierto protagonismo o liderazgo en la organización de la manifestación. ¿Cómo se puede «determinar razonablemente» que quien porta o exhibe una bandera o una pancarta «dirige» una concentración?. Como dijo el portavoz de IU en el debate que tuvo lugar en el Pleno del Senado, la responsabilidad en el ámbito sancionador administrativo tiene que demostrarse, no se puede deducir de determinados signos o indicios ${ }^{66}$.

Por otro lado, tampoco es de recibo atribuir a los convocantes una suerte de responsabilidad presunta de carácter objetivo (sin dolo o culpa) por los incidentes o daños que puedan causar los manifestantes. Por esa razón, el informe del CGPJ recomendó la supresión de este precepto (art. 29.3 del anteproyecto). Porque lo

64 En cuanto a las responsabilidad de los mayores de 14 y menores de 18 , se prevé que cuando sea declarado autor de los hechos cometidos un menor de 18 años no emancipado o una persona con la capacidad modificada judicialmente responderán solidariamente con él de los daños y perjuicios ocasionados sus padres, tutores, curadores, acogedores o guardadores legales o de hecho (art. 42.3).

65 En el artículo 23 de la LOPSC de 1992 se empleaba el término «inspiradores», en lugar de «directores». En el Proyecto se suprime la alusión a los «inspiradores» como posible responsables de las infracciones cometidas en el curso de las reuniones o manifestaciones. Para el Consejo de Estado, se trata de una palabra de imprecisos contornos y poco acorde con la seguridad jurídica. La inspiración cae además dentro de los ámbitos protegidos por los artículos 16 y $20 \mathrm{CE}$. Y formula al respecto una observación de carácter esencial.

66 DSS, cit., p. 14091. No lo ve así el Consell de Garanties Estatutàries, que en su dictamen concluye que «difícilmente el legislador puede llegar a prever con todo detalle las circunstancias que se puedan llegar a dar. La fijación de un listado ejemplificativo de hechos base no constituye un criterio que por si solo sea suficiente para determinar la condición de director de la reunión o manifestación, sino que el aplicador de la norma deberá proceder... a un juicio de valor de acuerdo con las reglas de la lógica y la experiencia, que constituyen un juicio constitucionalmente legítimo» (pp. 107-108). 
que se establece no es la responsabilidad de los organizadores y promotores de una reunión o manifestación en lugar de tránsito público por el incumplimiento de las obligaciones impuestas por los artículos 9, 10 y 11 de la LODR (la de comunicación previa, entre otras), sino la responsabilidad por cualquier infracción que pudiera cometerse en esa reunión o manifestación, sin que tenga que acreditarse de modo preciso e individualizado su relación con los hechos tipificados en las mismas. Por lo que más que responsables por una conducta propia, son responsables de la de un tercero - el autor-, lo que contraviene el principio de personalidad de la sanción. Las dificultades para probar la autoría —en particular la inducción o la cooperación necesaria - no pueden justificar un supuesto de responsabilidad conjunta con contravención del principio de taxatividad y de culpabilidad $^{67}$.

En relación con este asunto, el régimen de responsabilidad de los organizadores por los altercados que puedan producirse en el curso de la manifestación, conviene recordar que, como ha puesto de relieve la Comisión de Venecia, los organizadores de una reunión no deben ser considerados responsables de los actos realizados por manifestantes individuales o los disturbios provocados por terceros no participantes, siempre que hayan desplegado esfuerzos razonables para garantizar el carácter pacífico de la misma. Imputarles esa responsabilidad (por conductas cometidas por otros que no podían prever razonablemente) sería una reacción manifiestamente desproporcionada y tendría un efecto inhibidor que desalentaría el libre ejercicio del derecho de reunión ${ }^{68}$.

El artículo 33 establece con carácter general las circunstancias y criterios que han de tenerse en cuenta para la graduación de las sanciones, con el fin de garantizar que las multas que imponga la Administración en este ámbito guarden la debida proporción con la gravedad del hecho constitutivo de la infracción. Dentro de los límites previstos para las infracciones muy graves y graves, las multas se dividirán en tres tramos de igual extensión, correspondientes a los grados mínimo, medio y máximo, de tal forma que como regla general la comisión de una infracción determinará la imposición de la multa correspondiente en grado míni-

67 Informe del CGPJ, p. 52. El Consell de Garanties Estatutàries discrepa también de esa conclusión. Aunque parte de la premisa de que el Derecho administrativo sancionador está regido por el principio de responsabilidad individual, entiende que ser «director» de la manifestación o reunión implica claramente una participación directa en su organización y la asimilación que hace este precepto entre los sujetos responsables y los organizadores o promotores no vulnera el principio de responsabilidad individual, ni tampoco el de culpabilidad (pp. 106-107).

$68 \mathrm{La}$ jurisprudencia del TEDH apunta en la misma dirección. En el asunto Gün y otros c. Turquía (2013) consideró injustificada la condena impuesta a los organizadores de una manifestación al término de la cual un grupo reducido de asistentes actuaron de forma violenta. El Tribunal tuvo en cuenta que la manifestación ilegal llegó a celebrarse y se disolvió pacíficamente sin que interviniera la policía. La violencia estalló poco después entre la policía y una decena de manifestantes que causaron daños. Los demandantes no fueron condenados por haberse comportado de forma violenta o por haber incitado a los participantes a la violencia, sino por haber organizado la manifestación. Pero sus intenciones eran completamente pacíficas y la policía no logró identificar y detener a los autores de unos actos de los que no se podía responsabilizar a los demandantes. 
mo. Pero podrá sancionarse con multa en grado medio cuando concurra, al menos, una de las siguientes circunstancias agravantes: reincidencia ${ }^{69}$, violencia, amenaza o intimidación, uso de prendas u objetos que cubran el rostro, impidiendo o dificultando la identificación y utilización de menores de edad o personas con discapacidad necesitadas de especial protección o en situación de vulnerabi$\operatorname{lidad}^{70}$.

En cada grado, se tendrán en cuenta para la individualización de la multa los siguientes criterios: la entidad del riesgo producido para la seguridad ciudadana o la salud pública, la cuantía del perjuicio causado; la trascendencia del perjuicio para la prevención, mantenimiento o restablecimiento de la seguridad ciudadana; la alteración ocasionada en el funcionamiento de los servicios públicos o en el abastecimiento de bienes y servicios; el beneficio económico obtenido, el grado de culpabilidad y la capacidad económica del infractor. Con el establecimiento de estos criterios se limita la libre discrecionalidad del órgano sancionador a la hora de calibrar el alcance de la sanción.

\section{b) Infracciones y sanciones (Sección $2 .^{a}$ )}

Las infracciones se clasifican en muy graves, graves y leves (art. 34). Se tipifican cuatro conductas especialmente lesivas para la seguridad ciudadana como infracciones muy graves, una novedad, porque la Ley de 1992 no contenía una relación de infracciones muy graves, sino que permitía calificar como tales determinadas infracciones graves en función de las circunstancias concurrentes, una decisión que podía adoptar el instructor con un amplio margen de discrecionalidad.

Se incrementa notablemente el número de infracciones. Son 44 en total ( 4 muy graves, 23 graves y 17 leves), frente a las 26 de la Ley anterior (28 en su versión original). Ya indicamos que algunas de ellas sancionan conductas que eran constitutivas de falta contra el orden público hasta la aprobación de la reforma del Código Penal que suprimió las faltas. Esta despenalización, que no es una medida caprichosa, porque trata de dar respuesta a la saturación de los juzgados de lo Penal, tiene, sin embargo, efectos perversos que afectan de lleno al ejercicio efectivo del derecho a la tutela judicial. Como bien explica en su informe el CGPJ, «la tipificación de las faltas como infracciones administrativas conlleva importantes consecuencias: a) La sanción no se impone por un órgano judicial, sino por la Administración, a quien corresponderá la valoración del comporta-

69 Por la comisión en el término de dos años de más de una infracción de la misma naturaleza, cuando así haya sido declarado por resolución firme en vía administrativa.

70 Las infracciones solo deben sancionarse con una multa en grado máximo cuando los hechos sean de una especial gravedad y así lo justifiquen el número y la entidad de las circunstancias concurrentes y los criterios previstos en ese mismo apartado (art. 33.2) 
miento, sin perjuicio de la posibilidad de revisión ante órganos jurisdiccionales ${ }^{71}$; b) Para la revisión judicial de la sanción administrativa, será necesario el pago de tasas judiciales, que no existen en el procedimiento penal ${ }^{72}$; c) En el procedimiento sancionatorio administrativo las declaraciones de los agentes que formulen denuncia gozan de valor probatorio de los hechos denunciados, mientras que en el procedimiento penal tienen en valor de simples declaraciones testificales (artículo 717 LECrim); d) La multa penal se impone teniendo en cuenta la capacidad económica del denunciado (artículo $53 \mathrm{CP}$ ), mientras que para la determinación de la multa administrativa no se toman en cuenta esta circunstancia; e) La sanción firme administrativa será inscrita en un Registro Central de Infracciones, mientras que la condena penal por falta no es susceptible de inscripción en registro alguno» ${ }^{73}$. A lo que hay que añadir otra consecuencia paradójica: las sanciones administrativas van a ser más severas que las que se imponían a quienes cometían una falta. En efecto, el importe de las sanciones económicas que se pueden imponer excede con mucho del que acostumbraban a imponer los jueces por las faltas equivalentes.

Durante la tramitación parlamentaria del proyecto, todos los grupos de la oposición mostraron sus reservas en relación con el trasvase del procedimiento penal al administrativo sancionador y el control ex post de las sanciones por la jurisdicción contencioso-administrativa, una vez agotada la vía administrativa (los recursos de alzada o de revisión no suelen ser eficaces porque no ofrecen garantías de imparcialidad). Coinciden en que esta reforma, que se traduce en una disminución de las garantías para los ciudadanos, se hace para huir del control judicial. Se pretende sustraer esa competencia a los tribunales ordinarios porque al Gobierno no le gusta cómo están resolviendo estos asuntos los jueces penales, le parecen demasiado garantistas, demasiado «blandos». Prueba de ello es que en

71 En palabras del Consejo de Estado, «la intervención directa de un juez imparcial se sustituye, así, por la potestad sancionadora de la Administración, cuya actuación está regida por el principio de autotutela, con todas las consecuencias que ello tiene para el particular afectado, que habrá de asumir las cargas inherentes a todo procedimiento administrativo y, en su caso, del ulterior proceso contencioso-administrativo». En realidad, no supone necesariamente un ahorro de medios, sino el traslado de la carga de trabajo de la jurisdicción penal a la contencioso-administrativa (Dictamen 358/2013, de 27 de junio de 2013, sobre el Proyecto de LO por la que se modifica la LO 10/1995, de 23 de noviembre, del Código Penal). Es patente, por otra parte, el desequilibrio que existe entre las partes en el proceso contencioso-administrativo: el ciudadano se ve obligado a recurrir un acto de la Administración que, normalmente, habrá sido ya ejecutado (en virtud del principio solve et repete, tendrá que pagar la multa correspondiente), debiendo personarse con abogado y habiendo abonado previamente la tasa correspondiente, frente a una Administración que cuenta con su propio servicio jurídico y que está exenta del pago de tasas judiciales. Es un factor disuasorio en el ejercicio de derechos y libertades, pues, una vez que las sanciones sean firmes, en caso de impago, se iniciará un procedimiento de embargo.

72 Con el agravante de que rige el principio del vencimiento en orden a la atribución de las costas, de acuerdo con el régimen, ciertamente disuasorio para el administrado, establecido tras la reforma de la LJCA introducida por la Ley 37/2011, de 10 de octubre, de medidas de agilización procesal, con la intención de reducir la litigiosidad en este orden jurisdiccional.

73 Informe sobre el anteproyecto de LOPSC,.., pp. 57-58. 
la mayoría de las ocasiones en las que se ha llevado ante los tribunales a manifestantes o activistas acusados de desacato, de desobediencia, de atentado, o de desórdenes públicos, los jueces los han absuelto. Además, la Administración se convierte en juez y parte. En el procedimiento penal Administración y ciudadanos están en el mismo plano. En el contencioso, no.

Con respecto al cuadro general de infracciones, se formularon en los debates parlamentarios diversas críticas. Por un lado, se puso en duda la vinculación con la protección de la seguridad ciudadana de algunas de ellas, como las que sancionan la pérdida o el extravío de la documentación personal o el escalamiento de edificios sin autorización, aunque no tenga ninguna consecuencia. Por otro lado, se subrayó el hecho de que algunas de las infracciones de nueva creación tienen nombres y apellidos, van dirigidas contra colectivos o entidades perfectamente identificados, con la intención de poner coto a sus actividades reivindicativas. Como señaló el diputado Sánchez Amor, nos encontramos con una cláusula top manta, una cláusula Greenpeace, una cláusula Femen, una cláusula okupa, una cláusula desahucio, o una cláusula botellón ${ }^{74}$.

Otras críticas apuntaban a la inclusión en la Ley de conceptos jurídicos indeterminados que dejan un peligroso margen a la interpretación y generan incertidumbre. Algunas infracciones están descritas en términos excesivamente amplios, no lo suficientemente precisos y taxativos, por lo que distan mucho de cumplir las exigencias del principio de tipicidad. Hay que consignar, por último, las que ponen el foco en el riesgo de doble tipificación (en la LOPSC y en el Código Penal) de determinadas conductas (en relación por ejemplo con el consumo de drogas).
a) Infracciones muy graves (art. 35)

Nos ocuparemos únicamente de dos de ellas:

1. Las reuniones o manifestaciones no comunicadas o probibidas en infraestructuras o instalaciones en las que se prestan servicios básicos para la comunidad o en sus inmediaciones, así como la intrusión en los recintos de éstas, incluido su sobrevuelo, cuando, en cualquiera de estos supuestos, se haya generado un riesgo para la vida o la integridad física de las personas ${ }^{75}$.

La Disposición adicional sexta especifica cuáles son esas infraestructuras e instalaciones a los efectos de esta Ley: centrales nucleares, petroquímicas, refine-

74 DSCD, cit., p. 62.

75 El último inciso se añadió tras la aceptación por la ponencia de la enmienda n. ${ }^{\circ} 217$ del Grupo Popular en el Congreso, que proponía que para considerar esa conducta como infracción muy grave debía generar un riesgo para la vida o la integridad física de las personas, de modo que cuando no tiene esa entidad y sólo produce una interferencia en el funcionamiento de las instalaciones o infraestructuras, se sancionará como infracción grave (prevista en el art. 36.9). 
rías y depósitos de combustible; puertos, aeropuertos y demás infraestructuras de transporte; servicios de suministro y distribución de agua, gas y electricidad e infraestructuras de telecomunicaciones ${ }^{76}$.

Este precepto fue examinado por el Consell de Garanties Estatutàries, que en su dictamen (pp. 103-104) llegó a la conclusión de que la expresión «o en sus inmediaciones» vulneraba el 25.1 CE, porque carece de la concreción y claridad que exige el principio de tipicidad. Dicho de otro modo, no permite identificar con la mínima precisión el área de influencia que está afectada por esta infracción.

4. La proyección de haces de luz, mediante cualquier tipo de dispositivo, sobre los pilotos o conductores de medios de transporte que puedan deslumbrarles o distraer su atención y provocar accidentes.

Se trata de combatir una nueva forma de vandalismo, básicamente aeronáutico, que obviamente no existía en el año 1992, y que se ha multiplicado exponencialmente en los últimos años, poniendo en grave riesgo la vida de muchas personas $^{77}$.

b) Infracciones graves (art. 36)

Centraremos nuestra atención en las más controvertidas.

1. La perturbación de la seguridad ciudadana en actos públicos, espectáculos deportivos o culturales, solemnidades y oficios religiosos u otras reuniones a las que asistan numerosas personas, cuando no sean constitutivas de infracción penal.

Esta infracción suscita dudas desde una doble perspectiva. Por un lado, su posible solapamiento con la conducta tipificada como delito de desórdenes públi$\cos (557 \mathrm{CP})$. Por otro, no cumple, a juicio del Consell de Garanties Estatutàries, las exigencias de certeza, precisión y claridad que impone el principio de tipicidad. La conducta se describe en términos amplios e indeterminados, no se concreta, por ejemplo, cuál debe ser el nivel de perturbación que ha de tener la actuación infractora y qué resultado debe producir. Se formula más bien como una

76 En el anteproyecto no se incluía esa disposición, lo que llevó al Consejo de Estado a formular una objeción de carácter esencial. Aunque varios preceptos hacían referencia a tales infraestructuras críticas como elementos configuradores de distintas infracciones, el catálogo de dichas estructuras críticas era secreto (art. 4.3 del Reglamento para su protección, aprobado por RD 704/2011, de 20 de mayo). La publicidad es inherente a la seguridad jurídica, de tal suerte que no puede preverse una infracción cuando no es posible conocer si se está cometiendo o no. La omisión se subsana en el proyecto.

77 El ministro del Interior facilitó a los diputados las cifras proporcionadas por la Agencia Española de Seguridad Aérea. En 2010 se produjeron 120 casos de deslumbramiento de pilotos de aeronave con láser, 446 en el año 2011, 490 en el año 2012 y 634 el 2013 (DSCD, cit., p. 27). La proyección de esos mismos haces de luz sobre miembros de las Fuerzas y Cuerpos de Seguridad para impedir o dificultar el ejercicio de sus funciones, se castiga como infracción leve (art. 37.6). 
cláusula abierta u omnicomprensiva que permite sancionar cualquier perturbación, incluso leve. De ahí que infrinja también el principio de proporcionalidad, porque en este último supuesto la sanción mínima prevista (600 euros) es muy elevada.

2. La perturbación grave de la seguridad ciudadana que se produzca con ocasión de reuniones o manifestaciones frente a las sedes del Congreso de los Diputados, el Senado y las asambleas legislativas de las comunidades autónomas, aunque no estuvieran reunidas, cuando no constituya infracción penal.

Son objeto de sanción las reuniones o manifestaciones que no hayan sido comunicadas (las comunicadas y no prohibidas serían lícitas) y ocasionen además perturbaciones graves de la seguridad ciudadana. Insiste el ministro en sus intervenciones en que se exige la concurrencia de ambas circunstancias. Como se desprende del tenor literal de la norma, resulta indiferente que la asamblea esté reunida o no. Si estuviese reunida, tales conductas podrían constituir un delito contra las instituciones del Estado si llegasen a alterar el normal funcionamiento de la Cámara (artículo 494 CP). Pero si no están reunidas (o ni siquiera abiertas, porque es un día festivo) y no se perturba el funcionamiento de estas instituciones, no tiene ningún sentido imponer una sanción; no se alcanza a comprender el motivo de esa protección singular, privilegiada, de unos edificios oficiales.

En esa dirección apunta el recurso de inconstitucionalidad interpuesto por los diputados de la oposición, que impugnan este precepto porque supone, a su juicio, una restricción injustificada del ejercicio del derecho de reunión. Ciertamente, la Constitución proclama que las Cortes Generales son inviolables y prohíbe la presentación directa de peticiones por manifestaciones ciudadanas (art. 77 $\mathrm{CE}$ ). Pero estas previsiones tienen por objeto garantizar la independencia y la inviolabilidad de las deliberaciones parlamentarias, cuando las Cámaras están reunidas, no de sus edificios, por emblemáticos que $\operatorname{sean}^{78}$.

4. Los actos de obstrucción que pretendan impedir a cualquier autoridad, empleado público o corporación oficial el ejercicio legítimo de sus funciones, el cumplimiento o la eje-

78 A la misma conclusión llega en su dictamen el Consell de Garanties Estatutàries. Ante la indefinición del tipo, se pregunta cuál es el bien jurídico que en realidad se pretende proteger con la conducta proscrita. La localización del desorden en un lugar tan relevante como son las inmediaciones de las sedes de las cámaras parlamentarias, sugiere que el bien jurídico protegido debería ser el normal funcionamiento de estas y la inviolabilidad de sus miembros (lo que parece deducirse también de la referencia a que la conducta no constituya infracción penal), pero lo cierto es que el precepto pone el foco en la alteración de la seguridad ciudadana. Por otra parte, la perturbación grave de la seguridad ciudadana, con motivo de cualquier reunión o manifestación, ya está sancionada expresamente. A las anteriores consideraciones se añade que la identificación del lugar donde debe producirse la reunión o manifestación, que resulta ser un elemento primordial del tipo, no se determina con la precisión necesaria. La expresión «frente a las sedes» no permite acotar con exactitud la zona dentro de la cual resulta aplicable la infracción (a diferencia de lo que pasa en normas parecidas del derecho comparado, como la Police Reform and Social Responsability Act de 2011 para Inglaterra y Gales, que fijan un determinado perímetro). 
cución de acuerdos o resoluciones administrativas o judiciales, siempre que se produzcan al margen de los procedimientos legalmente establecidos y no sean constitutivos de delito.

Esta es la cláusula PAH (Plataforma de Afectados por la Hipoteca) o «antidesahucios», que tiene en su punto de mira las concentraciones convocadas por organizaciones que tratan de impedir o dificultar la ejecución de las órdenes judiciales de desahucio. Se incluye para poder sancionar conductas de obstrucción que no constituyan delito $(550$ y $556 \mathrm{CP}$ ). Suscribimos en todo caso la observación formulada por el CGPJ en su informe sobre el anteproyecto: habría que precisar que sólo pueden sancionarse aquellos actos de obstrucción de una cierta entidad, que sean idóneos e inequívocos.

11. La solicitud o aceptación por el demandante de servicios sexuales retribuidos en zonas de tránsito público en las proximidades de lugares destinados a su uso por menores, como centros educativos, parques infantiles o espacios de ocio accesibles a menores de edad, o cuando estas conductas, por el lugar en que se realicen, puedan generar un riesgo para la seguridad vial. Los agentes de la autoridad requerirán a las personas que ofrezcan estos servicios para que se abstengan de hacerlo en dichos lugares, informándoles de que la inobservancia de dicho requerimiento podría constituir una infracción del párrafo 6 de este artículo.

Es más que dudoso que esta conducta incida en la seguridad ciudadana, pero en su discurso de presentación del proyecto el ministro quiso aclarar que no se pretende perseguir a quien ejerce la prostitución ni entrar en el debate sobre su posible regulación, sino simplemente proteger unos bienes jurídicos que considera prevalentes, como son en un caso la protección de la infancia y en el otro la seguridad vial. En rigor, no se sanciona la oferta o aceptación de servicios sexuales retribuidos, sino la inobservancia del requerimiento de los agentes de la autoridad.

23. El uso no autorizado de imágenes o datos personales o profesionales de autoridades o miembros de las Fuerzas y Cuerpos de Seguridad que pueda poner en peligro la seguridad personal o familiar de los agentes, de las instalaciones protegidas o en riesgo el éxito de una operación, con respeto al derecho fundamental a la información.

Es, en mi opinión, un precepto claramente inconstitucional, que, deliberadamente o no (evitaré los juicios de intenciones), impide de hecho que puedan documentarse los posibles abusos o excesos policiales. Si a ello se añade la posibilidad de que los agentes del orden confisquen las grabaciones, podemos afirmar sin incurrir en ninguna hipérbole que este precepto propicia la impunidad de las actuaciones policiales. De hecho, el propio ministro reconoció en el curso del debate de totalidad que ésta era una reivindicación constante de los sindicatos policiales $^{79}$. La reclame quien la reclame, esa sobreprotección de las Fuerzas de Seguridad carece de justificación.

79 DSCD, cit., p. 50. 
En el anteproyecto se incluía también las imágenes o datos que atentasen contra su derecho al honor, a la intimidad o a la propia imagen, lo que habría supuesto en la práctica la interdicción de toda difusión de imágenes de policías captadas en el curso de una operación o actuación. Se suprimió esa referencia en el proyecto, pero habrá que estar atentos a la interpretación que se haga (que haga la Administración en primer término) de expresiones tan vagas como "poner en peligro su seguridad personal» o «el éxito de la operación», que pueden entenderse como un cheque en blanco para decomisar cámaras o móviles, imposibilitando así la prueba documental de los excesos que los agentes puedan cometer en el ejercicio de sus funciones ${ }^{80}$.

No hace falta insistir en el papel esencial que juegan en una democracia los medios de comunicación, como «perros guardianes» que informan sobre asuntos que revisten interés general y que la opinión pública tiene derecho a conocer. Más concretamente, los profesionales de la información asumen un rol importante en la cobertura de las manifestaciones, que son acontecimientos de interés público que tienen lugar en un espacio también público. Esa cobertura es crucial porque a menudo la reunión constituye para las personas que no tienen normalmente acceso a los medios el único medio de trasmitir al público sus argumentos y propuestas. Pero cumple además otra función: los reportajes gráficos, las imágenes grabadas y las informaciones de los medios son un elemento determinante a la hora de depurar las posibles responsabilidades tanto de los organizadores como de las fuerzas del orden. En muchos casos, son las únicas pruebas que pueden aportarse en el proceso judicial. Por eso, los periodistas han de tener garantizado su acceso sin restricciones a las reuniones públicas y no se les puede impedir que observen, graben o fotografíen las actuaciones policiales conexas. Del mismo modo que las fuerzas del orden pueden fotografiar o grabar el desarrollo de esas reuniones ${ }^{81}$.Sin embargo, en no pocas ocasiones se impide a periodistas debidamente acreditados dar cuenta de una reunión, sufren malos tratos e incluso se les detiene y se les requisa o confisca su material gráfico.

En relación con este asunto, reviste interés la STC 72/2007, de 16 de abril, que afirmó que el derecho a la propia imagen «no es absoluto o incondicionado, de suerte que existen circunstancias que pueden determinar que la regla general conforme a la cual es al titular de este derecho a quien, en principio, corresponde decidir si permite o no la captación y difusión de su imagen por un tercero, ceda a favor de otros derechos o intereses constitucionalmente legítimos, lo que ocurrirá en los casos en los que exista un interés público en la captación o difusión de la imagen y este interés público se considere constitucionalmente prevalente al

80 Casi todos los grupos de la oposición presentaron enmiendas proponiendo la supresión de este apartado, que constituye, a su juicio, una grave amenaza para la libertad de información.

81 Vid. la LO 4/1997, de 4 de agosto, por la que se regula la utilización de videocámaras por las Fuerzas y Cuerpos de Seguridad en lugares públicos y su Reglamento de desarrollo (RD 596/1999, de 16 de abril). 
interés de la persona en evitar la captación o difusión de su imagen» ${ }^{82}$. Como explican los diputados que promovieron el recurso de inconstitucionalidad contra la LOPSC, este precepto vulnera la libertad activa y pasiva de información consagrada en el artículo $20 \mathrm{CE}$, por cuatro motivos al menos ${ }^{83}$.

En primer lugar, porque establece una restricción previa administrativa, manifiestamente desproporcionada, al ejercicio de la libertad de información, sujetando su disfrute a una previa autorización Se trata pues de una prohibición general con reserva de autorización, porque se sanciona con carácter general e indiscriminado la obtención de imágenes o datos de los agentes de las fuerzas de seguridad, salvo que se esté autorizado ${ }^{84}$. A la hora de fijar los límites previos a la libertad de información, el legislador ha de someterse a los principios de proporcionalidad y ponderación. Y en este caso no los ha respetado, porque los bienes que se invocan para justificar su limitación preventiva no poseen el mismo rango constitucional. Además, los términos en los que se establece el supuesto de hecho que daría lugar a la necesidad de autorización son tan genéricos e indeterminados que de facto obligan a los informadores a solicitar autorización previa para dar cobertura informativa a cualquier hecho en el que puedan intervenir autoridades o miembros de las Fuerzas y Cuerpos de Seguridad ${ }^{85}$.

82 En este caso, la fotografía reproducía la imagen de una Sargento de la Policía Municipal de Madrid en el ejercicio de sus funciones, y había sido captada con motivo de un acto público (un desalojo por orden judicial, que para ser llevado a cabo precisó del auxilio de los agentes de la Policía Municipal, en un lugar público). Como dijo el Tribunal Constitucional en su Sentencia 192/1999, los agentes son a estos efectos personajes públicos en cuanto actúan en ejercicio de sus funciones, y, en consecuencia, deben soportar restricciones a sus derechos fundamentales en aras de la libertad de información en asuntos de relevancia pública. A esta doctrina se remite la Sentencia de 6 de marzo de 2014 del Juzgado de Instrucción n. ${ }^{\circ} 11$ de Madrid, dictada en un juicio seguido por una posible falta contra el orden público, a raíz de una denuncia presentada por dos Policías Municipales contra una mujer que les había recriminado su actitud al observar que solicitaban la documentación a un cámara que les estaba grabando en contra de las indicaciones de éstos, y ver cómo uno de ellos apartaba bruscamente la cámara con que se grababa. Los agentes, concluye la sentencia, «llevaron a cabo una actuación que carecía de cobertura legal, pues ni existe prohibición de filmar en el espacio público, ni la imagen de los agentes».

83 Vid. pp. 26-44 del recurso.

84 Se recuerda en este punto la doctrina acuñada en las SSTC 56 y 57/2004. En estas Sentencias, el Tribunal Constitucional consideró que, dado el valor superior de la libertad de información en un sistema democrático, es contraria al artículo 20.1 d) CE la prohibición general de acceso de los medios de comunicación a las salas de vistas o a las actuaciones judiciales sin la previa autorización de las salas de gobierno. Esa prohibición es incompatible con la regulación constitucional, que establece precisamente un régimen de «habilitación general con reserva de prohibición», en el que tendrá que justificarse expresamente y de manera convincente en cada caso toda eventual limitación o prohibición de una actividad inicialmente permitida. En esta idea abunda también el dictamen del Consell de Garanties Estatutàries: «el ordenamiento constitucional no admite los controles sobre el ejercicio del derecho a la información con una finalidad meramente preventiva o de aseguramiento y protege la difusión y la comunicación de toda información que cumpla con los requisitos de veracidad e interés o relevancia pública» (pp. 114 y 122).

85 Por lo que concierne a los datos de los agentes, la garantía del derecho fundamental a la protección de datos se refiere a los datos personales y no cabe duda de que entre ellos deben incluirse los datos profesionales del agente. La identidad derivada del número de placa, unidad, imagen del agente, etc., son datos personales, aunque en determinadas ocasiones puede prevalecer el interés general en su conocimiento. Por otro lado, esos datos ya son públicos, están a la vista en un lugar público, y se obtienen en el ejercicio de las fun- 
En segundo lugar, lo que la norma impugnada establece es una censura administrativa previa prohibida expresamente en el artículo $20.2 \mathrm{CE}^{86}$ : si se quiere informar captando y divulgando en su caso imágenes o datos de los agentes actuantes se debe obtener la autorización previa de la Administración. Una censura que la ley no puede establecer ni siquiera apelando a la protección de otros derechos fundamentales.

En tercer lugar, el artículo 36.23, en conexión con el artículo 19.2 del mismo texto legal ${ }^{87}$, autoriza el secuestro no judicial de material informativo, vulnerando así el artículo 20.5 CE, que prohíbe el secuestro administrativo de publicaciones o grabaciones. En efecto, se abre la puerta a que la Administración pueda acordar la incautación del material informativo si considera que el informador (profesional o simple ciudadano) ha captado imágenes o tomado datos de los agentes incurriendo en la mencionada prohibición. Y a que pueda hacerlo sin la existencia de un procedimiento contradictorio previo y sin autorización judicial. En nuestro sistema constitucional sólo tiene cabida un sistema «represivo», no preventivo, de restricción de este derecho fundamental. Por lo tanto, la ley puede establecer que quien tome imágenes o datos de los agentes con lesión de sus derechos fundamentales o de bienes dignos de protección constitucional podrá ser sancionado tras el pertinente procedimiento en el que se pruebe ese daño real y efectivo; pero es ilícito constitucionalmente establecer una prohibición previa y general con reserva de autorización administrativa, que permita además la incautación del material informativo por la Administración.

Por último, el legislador emplea términos jurídicamente indeterminados para describir el tipo de la infracción, lo que aumenta el margen de penumbra normativa en la que la Administración pública puede actuar discrecionalmente, e impide que el ciudadano o el informador pueda saber con un mínimo de certeza en qué casos infringe el precepto y se le puede ser incautar el material informativo. Se denuncia pues la violación del principio de taxatividad del artículo $25.1 \mathrm{CE}^{88}$.

ciones del agente, en una actuación pública. Han perdido, por tanto, su condición de información confidencial, lo que no quiere decir que se pueda hacer cualquier uso de esos datos, pero sí que su obtención en esas condiciones no lesiona el derecho fundamental a la protección de datos.

86 Los recurrentes recuerdan cómo se define este concepto en la STC 187/1999: «por censura previa debe tenerse cualquier medida limitativa de la elaboración o difusión de una obra del espíritu que consista en el sometimiento a un previo examen por un poder público del contenido de la misma...».

87 El artículo 19.2 permite la «la aprehensión durante las diligencias de identificación, registro y comprobación de armas, drogas tóxicas, estupefacientes, sustancias psicotrópicas u otros efectos procedentes de un delito o infracción administrativa».

88 Para los recurrentes, es evidente que «al ciudadano medio le es imposible saber si captar la imagen o los datos de los agentes puede poner en riesgo el éxito de una operación policial, que desconoce probablemente, o la seguridad del agente o de su familia, lo que siempre es un... futurible, una posibilidad incierta, o la de las instalaciones protegidas, lo que también es una especulación». Esa indeterminación deja en manos de la Administración, y en la mayoría de las ocasiones del mismo agente o del jefe del operativo policial, la decisión sobre si concurren o no tales razones en ese caso. Además, si tras ponderar las circunstancias concurrentes, el agente decide incautar el material informativo en ese preciso momento, se «frustra la posibilidad de ejercer la libertad de información, defraudando también el derecho a recibirla de los ciudadanos,... porque al 
c) Infracciones leves (art. 37)

Son cinco las que concitan nuestro interés.

1. La celebración de reuniones en lugares de tránsito público o de manifestaciones, incumpliendo lo preceptuado en los artículos 4.2, 8, 9, 10 y 11 de la LO 9/1983, de 15 de julio, cuya responsabilidad corresponderá a los organizadores o promotores.

Esta conducta ya estaba tipificada como infracción grave en el artículo 23.c) de la LOPSC de 1992. Ahora se califica de leve, lo que implica una reducción sustancial de la cuantía máxima de la multa (de 30.000 a 600 euros), y también de la mínima (de 300 a 100 euros). Y eso es sin duda una buena noticia. Cuando el tipo se refiere a los requisitos que establece la LODR se está pensando, naturalmente, en la obligación de los organizadores y promotores de comunicar previamente la convocatoria de la manifestación cuando ésta vaya a celebrarse en un lugar de tránsito público (de acuerdo con lo previsto en el art. $21 \mathrm{CE}$ ). A tenor de lo dispuesto en el artículo 8 LODR, deben cumplimentar este requisito por escrito, con una antelación mínima de diez días, si bien en casos de urgencia justificada ese plazo se reduce a 24 horas.

Para el Tribunal de Estrasburgo, la obligación de comunicación o preaviso sería compatible, en principio, con lo dispuesto en el artículo $11 \mathrm{CEDH}$, porque las autoridades han de estar en condiciones de asegurar el carácter pacífico de una reunión y preservar el orden público. No constituye por tanto una restricción excesiva ni razonable y su incumplimiento puede ser sancionado, siempre que sea de forma proporcionada ${ }^{89}$. La Comisión de Venecia ha precisado que la inclusión en la legislación nacional de una norma que exija notificar con antelación la celebración de una reunión no es una medida imprescindible. De hecho, no se contempla con carácter general en muchos países ${ }^{90}$. La exigencia de un preaviso sólo

tratarse de una actuación-restricción previa, impeditiva de la difusión de la información, en el caso de que judicialmente se amparase al ciudadano, no podría reponérsele en el libre ejercicio de su derecho fundamental al resultar imposible, ya que la información que se desea divulgar, la imagen o el dato, ya no existe». Pero eso no es todo. Al no regularse el procedimiento de obtención de la autorización, «la inseguridad jurídica se extiende a todos los aspectos relacionados con la autorización: ¿quién le proporciona la autorización?, ¿cómo?, ¿cómo recurrir el rechazo?, ¿ante qué instancia?, etc.». La Defensora del Pueblo, en su Recomendación, ya citada, sobre la LOPSC, urgió al Gobierno a elaborar instrucciones que garanticen la interpretación y aplicación de esta infracción del modo más favorable a la plena efectividad de la libertad de información. En particular, no puede interpretarse en el sentido de que se exija una autorización administrativa previa para la difusión de tales imágenes o datos o de que sea posible una aprehensión de material informativo sin autorización judicial.

89 Vid., por ejemplo, la decisión del Tribunal en el asunto Skiba c. Polonia (2009). Pero con flexibilidad a la hora de comprobar el cumplimiento del plazo: en el caso Kuznetsov c. Rusia (2008), el TEDH estimó que «la violación formal del plazo de notificación no constituye una razón pertinente ni suficiente para comprometer la responsabilidad administrativa del organizador». En ese caso, el carácter tardío de la notificación no había impedido a las autoridades prepararse correctamente para la reunión.

90 Líneas Directrices de la Oficina para las Instituciones Democráticas y los Derechos del Hombre de la OSCE y la Comisión de Venecia del Consejo de Europa sobre la libertad de reunión pacífica —2. a edición- 
tiene sentido cuando tiene como finalidad proporcionar a las autoridades públicas la información necesaria para que éstas puedan adoptar las medidas adecuadas para facilitar la libertad de reunión y proteger el orden y la seguridad públicas, así como los derechos y libertades de terceros.

En principio, la regulación de la LODR parece correcta y los plazos son razonables. Pero plantea dos problemas de gran calado. En primer lugar, no da respuesta al desafío que representan las movilizaciones organizadas a través de teléfonos móviles, SMS, e-mails o las redes sociales. Una pujante realidad que desborda los rígidos corsés legales y tiene que abordarse para no agravar un desfase que se hace cada vez más patente. Una reunión espontánea es aquella que se convoca como reacción inmediata y urgente a un hecho o acontecimiento imprevisto (la presencia no anunciada de una personalidad, por ejemplo), a otra reunión o a un discurso o declaración. En la medida en que guarda estrecha conexión temporal y material con el acontecimiento que la desencadena, que sirve de detonante, no se puede anunciar previamente. A veces, un mensaje difundido de forma instantánea y a gran escala a través de internet provoca que una multitud se reúna en un determinado lugar sin publicidad ni planificación o invitación previa. En los casos en que exista un organizador identificable, éste no puede observar el plazo legal de notificación previa, porque cualquier retraso debilitaría el mensaje que se pretende expresar y frustraría el objetivo perseguido ${ }^{91}$.

En varios de sus documentos ${ }^{92}$, la Comisión de Venecia ha insistido en que la garantía de la libertad de reunión no debe circunscribirse a las formas tradicionales, sino que ha de estar abierta a otras nuevas, como las flashmobs, cada vez más frecuentes en un entorno digital ${ }^{93}$. La posibilidad de reaccionar de forma inmediata ante un acontecimiento imprevisto es «un elemento esencial de la libertad de reunión» y su protección es «esencial para el funcionamiento de las modernas democracias». Cuando la legislación exige una notificación previa, debería prever explícitamente una excepción en aquellos casos en que resulta imposible respetar el plazo establecido o bien un plazo reducido que permita al organizador notificar a las autoridades tan pronto como sea posible ${ }^{94}$. Pero incluso cuando la ley no

aprobadas por la Comisión de Venecia el 4 de junio de 2010, pp. 10, 61 y 65. La Comisión considera una buena práctica exigir un preaviso únicamente si el número previsto de participantes es elevado y no para determinados tipos de reuniones (las que no afecten al tráfico por ejemplo).

91 Líneas directrices..., cit., pp. 7 y 65-66.

92 Líneas directrices..., cit., p. 67.

93 Una variante de manifestación espontánea son las flashmobs, reuniones improvisadas, que se convocan rápidamente y que además son efímeras (son de corta duración y buscan un efecto sorpresa).

94 Las enmiendas n. ${ }^{\circ}$ 129, presentada por La Izquierda Plural, y 248, formulada por J. Tardá (ERC), proponían la adición al artículo 37.1 del siguiente texto: «Se exceptuarán de esta infracción las manifestaciones espontáneas que vengan desencadenadas por acontecimientos imprevistos y que constituyen respuestas inmediatas a éstos, en los que no ha sido posible cumplir con las formalidades de la notificación previa». En otra enmienda, la n. ${ }^{\circ} 160$ del Grupo Socialista, se propone que sólo constituya infracción la conducta prevista «si se han producido actos de violencia» (BOCG. Congreso de los Diputados, serie A, n. ${ }^{\circ} 105-2$, de 04/11/2014, pp. 82, 99 y 165 ). 
contempla esa excepción, las autoridades han de proteger y facilitar siempre las reuniones espontáneas cuando revistan un carácter pacífico ${ }^{95}$.

En segundo lugar, no nos parece correcta la aplicación que se ha hecho de la norma prevista en la LOPSC de 1992. Los agentes de policía suelen identificar a los asistentes a una manifestación no comunicada como medida necesaria para tramitar la correspondiente denuncia. A tenor de la información recabada por las organizaciones de defensa de los derechos civiles, en los últimos años se ha generalizado la práctica consistente en someter a los participantes en este tipo de manifestaciones a comprobaciones masivas e indiscriminadas de identidad y se ha registrado un aumento significativo en el número y la cuantía de las multas impuestas no sólo por promover, sino también por asistir a reuniones no comunicadas, sanciones estas últimas que carecen, a mi juicio, de cobertura legal, porque el art. 23.c), al igual que el 37.1 de la nueva Ley, atribuye la responsabilidad únicamente a los organizadores o promotores. Aunque muchas de las sanciones económicas impuestas a simples participantes son anuladas cuando se recurren ante los tribunales, entre otras razones porque una persona que asiste a una manifestación no comunicada no tiene por qué conocer esa circunstancia, y otras no se ejecutan, lo cierto es que tanto las identificaciones sistemáticas como la apertura de expedientes sancionadores pueden tener un efecto disuasorio, que acabe desalentando la participación en reuniones públicas.

Centrándonos en la posible inconstitucionalidad del art. 37.1 LOPSC, para los diputados que firmaron el recurso contra la LOPSC es evidente que la infracción prevista en dicho precepto vulnera el derecho reconocido en el artículo 21 CE si se pone en conexión con lo previsto en el artículo 30.3 de la misma Ley, que, como vimos, amplía con carácter general la responsabilidad a quienes por determinadas actuaciones o manifestaciones pudieran considerarse razonablemente organizadores ${ }^{96}$. Porque, como ha señalado el TEDH, «la libertad de participar en una manifestación pacífica reviste tal importancia que una persona no puede ser sancionada por haber participado en una reunión no prohibida, salvo

95 El Comisario para los Derechos Humanos del Consejo de Europa, en su Informe sobre España de 9 de octubre de 2013, subrayaba la necesidad de que las autoridades garanticen la libertad de reunión, incluso en el contexto de manifestaciones «espontáneas» no notificadas. En la misma línea, la jurisprudencia del TEDH ha admitido que en determinadas circunstancias el derecho a celebrar reuniones espontáneas prevalece sobre la obligación de preaviso, como excepción a la regla general: cuando sea indispensable reaccionar inmediatamente a un suceso o acontecimiento mediante una manifestación, porque de otro modo, si se pospone, la respuesta sería ya obsoleta, tardía. Vid., por ejemplo, las SSTEDH en los asuntos Bukta y otros c. Hungría (2007), y Éva Molnár c. Hungría (2008).

96 Vid. pp. 14 a 19 del recurso. La consecuencia de ambas disposiciones constituye una restricción desproporcionada del derecho de reunión, que queda afectado en su propia esencia, por cuanto podrán ser sancionados quienes simplemente hayan participado en una concentración espontánea o que no haya sido previamente comunicada (p. 19). El Consell de Garanties Estatutàries no aprecia, en cambio, motivos de inconstitucionalidad en el artículo 37.1 LOPSC. 
que haya incurrido personal y directamente en un comportamiento reprochable» (STEDH de 5 de marzo de 2009, en el caso Barraco c. Francia) ${ }^{97}$.

4. Las faltas de respeto y consideración cuyo destinatario sea un miembro de las Fuerzas y Cuerpos de Seguridad en el ejercicio de sus funciones de protección de la seguridad, cuando estas conductas no sean constitutivas de infracción penal.

$\mathrm{Al}$ amparo de este precepto los agentes del orden pueden denunciar por la vía administrativa a quienes ellos consideran que les han faltado al respeto ${ }^{98}$. Este precepto no vulnera, según el Consell Garanties Estatutàries, el principio de taxatividad, aunque adolece de un cierto grado de indeterminación, por lo que será necesario que el aplicador del derecho lleve a cabo una valoración no arbitraria, adecuada y razonable, que tenga en cuenta el contenido de las expresiones, las circunstancias de las personas, de tiempo y de lugar, así como la ocasión en la que han sido proferidas ${ }^{99}$.

7. La ocupación de cualquier inmueble, vivienda o edificio ajenos, o la permanencia en ellos, en ambos casos contra la voluntad de su propietario, arrendatario o titular de otro derecho sobre el mismo, cuando no sean constitutivas de infracción penal. Asimismo la ocupación de la vía pública con infracción de lo dispuesto por la Ley o contra la decisión adoptada en aplicación de aquella por la autoridad competente. Se entenderá incluida en este supuesto la ocupación de la vía pública para la venta ambulante no autorizada.

Son dos conductas que tienen en común una ocupación contraria a la ley, si bien en un caso se trata de la ocupación de un inmueble o la permanencia en él contra la voluntad de su titular en ambos casos, y en el otro de una ocupación privativa de una parte de la vía pública o de un espacio público de uso común general con infracción de la ley. Para disipar dudas, se incluye expresamente un supuesto frecuente de uso privativo de la vía pública, como es el que se produce con motivo de la venta ambulante no autorizada, sin perjuicio de las sanciones en que se pueda incurrir, con arreglo a la normativa autonómica y local correspondiente, o de la comisión incluso de una infracción penal (si se trata de productos de imitación o falsificados).

97 En esa misma línea, la STEDH de 14 de octubre de 2014, en el caso Yılmaz Yıldız y otros c. Turquía, que trae causa de una multa impuesta a los demandantes por haber participado en diversas concentraciones pacíficas ante varios hospitales, consideró que, a la vista de las circunstancias, la sanción administrativa por participar en una manifestación pacífica resultó desproporcionada. Y puede tener un efecto de desaliento (chilling effects) que desincentive el ejercicio del derecho de reunión.

98 En el texto aprobado por el Pleno del Congreso se eliminó la referencia inicial a las injurias y también la alusión a una reunión o concentración al aceptarse sendas enmiendas en ese sentido. Se sancionan pues esas ofensas cuando los agentes estén en el ejercicio de sus funciones de protección de la seguridad, en los mismos términos que el vigente art. $634 \mathrm{CP}$. En todo caso, la denuncia comporta, por el valor probatorio atribuido al testimonio del agente (art. 53), el desplazamiento de la carga de la prueba de su exculpación al supuesto infractor, que podrá ser sancionado directamente por la Administración en ejercicio de su potestad de autotutela, mientras que un ciudadano ofendido o injuriado debe acudir en defensa de su honor a los tribunales.

99 Dictamen, cit., pp. 89-91. 
Es más que discutible la decisión de castigar en la LOPSC el incumplimiento de las normas o las órdenes de un propietario o arrendatario privado, en tanto no afecte a la seguridad ciudadana ${ }^{100}$. En este sentido, el Consell de Garanties Estatutàries recuerda en su dictamen que la actividad sancionadora de la Administración debe ceñirse al castigo de aquellas conductas que lesionan bienes jurídicos de titularidad colectiva, entre los que no se incluye los que afectan individualmente al patrimonio de las personas. Además, la forma en que se tipifica la ocupación de inmuebles es excesivamente abierta. Por un lado, no toda lesión del derecho de propiedad es susceptible de una sanción penal o administrativa, ya que el Derecho civil prevé las acciones necesarias para restablecer la integridad y el disfrute pacífico de los derechos del titular. Por otro, no se sabe cuál es el bien jurídico protegido, porque no se establece una conexión directa y clara con la protección de la seguridad ciudadana. Para el Consell, esa incertidumbre sobre cuál es el alcance y la finalidad de la infracción y el bien jurídico que se pretende proteger vulnera los principios de tipicidad y seguridad jurídica (arts. 25.1 y $9.3 \mathrm{CE})^{101}$.

11. La negligencia en la custodia y conservación de la documentación personal legalmente exigida, considerándose como tal la tercera y posteriores pérdidas o extravíos en el plazo de un año $0^{102}$.

No se alcanza a comprender el motivo que ha llevado al legislador a introducir esta nueva infracción (en la Ley anterior sólo se sancionaba el incumplimiento de la obligación de obtener la documentación personal) para castigar una conducta «insignificante», que es el término que utiliza el CGPJ en su informe. Varios grupos pidieron la supresión de este apartado, porque consideraban que no se debería sancionar la simple pérdida o extravío si no existe dolo o negligencia (y ésta no se puede presumir). Además, en estos casos ya se cobra la tasa de expedición correspondiente. Se podría incrementar la cuantía de esa tasa, pero no castigar como una infracción una conducta que difícilmente puede afectar a la seguridad ciudadana.

13. Los daños o el deslucimiento de bienes muebles o inmuebles de uso o servicio público, así como de bienes muebles o inmuebles privados en la vía pública, cuando no constituyan infracción penal

Habrá que confiar en una interpretación cabal del término «deslucimiento», porque deja un amplio margen de discrecionalidad a las autoridades competentes. No parece razonable sancionar como «deslucimiento» la colocación de una simple pegatina o de un simple cartel informativo en una farola o cualquier grafiti.

100 Para el diputado Sixto Iglesias (Izquierda Plural) puede suponer una limitación del libre funcionamiento de los piquetes, porque se limita el acceso a los edificios para desarrollar labores de información (DSCD, Pleno Congreso, 11 noviembre 2014, p. 79).

101 Dictamen, cit. pp. 93-94.

102 En el anteproyecto el plazo se cifraba en cinco años. 
14. El escalamiento de edificios o monumentos sin autorización cuando exista un riesgo cierto de que se ocasionen daños a las personas o a los bienes.

Como ya se apuntó, este apartado se incluyó para disuadir a los activistas de Greenpeace, que suelen recurrir a esta práctica reivindicativa. En el proyecto de ley se sancionaba el escalamiento de edificios o monumentos sin autorización, sin más precisiones (art. 37.15). Pero, con buen criterio, la ponencia constituida en el Congreso aceptó la enmienda n. ${ }^{\circ} 160$ del Grupo Socialista y añadió el inciso final.

c) Las sanciones (art. 39 y ss)

La cuantía de las sanciones no varía mucho respecto de las previstas en la Ley anterior. Las infracciones muy graves se siguen sancionando con multa de 30.001 (antes 30.050) a 600.000 euros; las graves, con multa de 601 a 30.000 euros (se eleva la cuantía mínima de 300 a 601), y las leves, con multa de 100 a 600 euros (la horquilla oscilaba antes entre 0 y 300). No se mantienen intactas, como asegura una y otra vez el ministro, pero tampoco se incrementa su importe de forma sustancial, teniendo en cuenta los 23 años transcurridos. Se establecen además los tramos correspondientes a los grados máximo, medio y mínimo de las multas previstas por la comisión de infracciones graves y muy graves. De acuerdo con lo dispuesto en el artículo 40, las sanciones impuestas por infracciones muy graves prescribirán a los tres años, las impuestas por infracciones graves, a los dos años, y las impuestas por infracciones leves al año, computados desde el día siguiente a aquel en que adquiera firmeza en vía administrativa la resolución por la que se impone la sanción. Y a los solos efectos de apreciar la reincidencia en la comisión de infracciones tipificadas en esta Ley, se crea en el Ministerio del Interior un Registro Central de Infracciones contra la Seguridad Ciudadana (art. 43).

\section{La Disposición final primera: Régimen especial de Ceuta y Melilla ${ }^{103}$}

1. Se adiciona una disposición adicional décima a la LO 4/2000, de 11 de enero, sobre derechos y libertades de los extranjeros en España y su integración social, con la siguiente redacción:

«Disposición adicional décima. Régimen especial de Ceuta y Melilla.

1. Los extranjeros que sean detectados en la línea fronteriza de la demarcación territorial de Ceuta o Melilla mientras intentan superar los elementos de contención fronterizos para

103 Esta Disposición entró en vigor inmediatamente, el día siguiente al de su publicación en el BOE, a diferencia de los demás preceptos de la Ley, que lo hicieron el 1 de julio de 2015, de acuerdo con lo previsto en la Disposición Final Cuarta. 
cruzar irregularmente la frontera podrán ser rechazados a fin de impedir su entrada ilegal en España.

2. En todo caso, el rechazo se realizará respetando la normativa internacional de derechos humanos y de protección internacional de la que España es parte.

3. Las solicitudes de protección internacional se formalizarán en los lugares habilitados al efecto en los pasos fronterizos y se tramitarán conforme a lo establecido en la normativa en materia de protección internacional.»

Ya hicimos referencia a la génesis de esta Disposición y a las vicisitudes de su tramitación parlamentaria. El dato es relevante, porque se acude al expediente de presentar una enmienda en el último minuto (el día en que concluía el plazo de presentación de enmiendas) para introducir, de tapadillo, por la puerta de atrás, un régimen excepcional y eludir así los informes de los órganos con funciones consultivas. Se trata además de una enmienda cuyo contenido no guarda una clara conexión material con el objeto del proyecto de ley en el que se pretende incluir (STC 119/2011) (104 $^{\text {. }}$

Para el Gobierno, esta Disposición no pretende otra cosa que reforzar la protección de nuestras fronteras y clarificar el régimen jurídico que ya regía la actuación de las Fuerzas y Cuerpos de Seguridad del Estado en los perímetros fronterizos. Pero se va a encontrar con la firme oposición de todos los grupos, salvo el mayoritario, que rechazan unánimemente, sin fisuras, su iniciativa. Para estos grupos, de muy distinto signo político, lo que se busca realmente (con el eufemismo rechazo en frontera) es dar cobertura legal a una práctica ilegal (al margen de la ley), como son las devoluciones en caliente, las expulsiones sumarias, en las fronteras de Ceuta y Melilla. Este método expeditivo de devolución es contrario a la Constitución española, e infringe lo dispuesto en la LO 4/2000, de 11 de enero, sobre derechos y libertades de extranjeros en España (LOEx), en la Ley 12/2009, de 30 de octubre, reguladora del derecho de asilo y de la protección subsidiaria, en los tratados internacionales en materia de asilo y refugio y en los instrumentos internacionales de protección de los derechos humanos ${ }^{105}$.

104 Porque, como ponen de relieve los firmantes del primer recurso contra la LOPSC, la citada enmienda no regula con carácter general la actuación de Fuerzas de Seguridad en las fronteras españolas, sino que «introduce un nuevo procedimiento administrativo por la vía de hecho de expulsión de extranjeros aplicable únicamente en las fronteras de Melilla y Ceuta». Reconocen los recurrentes que lamentablemente esta práctica se ha generalizado, pero no deja de constituir «un fraude al procedimiento parlamentario de debate de los proyectos y proposiciones de ley» (p. 45). Discrepa de esa conclusión el Consell Garanties Estatutaries: a su juicio, no se puede decir que el contenido de esta enmienda no tenga relación con el texto enmendado y supone en realidad una nueva iniciativa legislativa (Dictamen, p. 126).

105 Vid. en este sentido el Informe jurídico «Rechazos en frontera. ¿Fronteras sin derechos?», suscrito por 15 prestigiosos profesores de Derecho y fechado el 13 de abril de 2015. Para estos juristas, «la práctica de las devoluciones sumarias sigue siendo radicalmente ilegal también a la luz de la nueva regulación» (p. 31). A su juicio, el régimen especial establecido sólo sería aplicable cuando se intenta el acceso por vía terrestre, como se desprende de la mención a los elementos de contención, estructuras permanentes que no existen en el mar. Y siempre que no se haya accedido aún a territorio español, por lo que no resulta aplicable a quienes hubiesen superado la valla interior, estén en la zona de intervallado o encaramados en cualquiera de las vallas, puesto que éstas están 
De entrada, conculca el derecho de cualquier extranjero a solicitar el asilo o la protección subsidiaria. Nuestra legislación obliga a las autoridades a seguir unos trámites. Si se detecta la presencia de un extranjero en la línea fronteriza (tras haber saltado la vallas que separan estas ciudades de Marruecos o haber accedido por mar), se le debe trasladar a una comisaría para proceder a su identificación, se debe cursar y tramitar cualquier petición individual de asilo o refugio que se solicite; y se le ha de proporcionar en todo caso la debida asistencia letrada (incluido un intérprete si es necesario) y la posibilidad de recurrir una resolución que sea contraria a sus intereses ${ }^{106}$. Y mientras no se resuelva el expediente administrativo legalmente previsto, no puede procederse a la devolución, ni de forma individual ni de forma colectiva, a Marruecos. Pues bien, con esta regulación «especial» se impide el ejercicio de esos derechos en el procedimiento de expulsión. Se faculta a las fuerzas de seguridad del Estado para expulsar inmediatamente al «intruso», sin ningún tipo de averiguación o comprobación, de interrogatorio, sin incoar el preceptivo expediente administrativo individual y sin dictar una resolución debidamente motivada ${ }^{107}$. Supone en definitiva la exclusión en estos supuestos de la normativa general establecida en el artículo 58.3 de la LOEX y en el artículo 23 del Reglamento de Extranjería (RD 557/2011). De acuerdo con estos preceptos, toda persona que pretenda entrar irregularmente en el país, incluidos los que sean interceptados en la frontera o en sus inmediaciones, debería ser objeto de un procedimiento de devolución, perfectamente reglado, con audiencia del interesado y las demás garantías previstas en el artículo 20.2 de la LOEX $^{108}$.

La devolución en caliente es una simple vía de hecho, una actuación material que no sigue procedimiento alguno ${ }^{109}$, de manera que la decisión de devolu-

ubicadas íntegramente en territorio nacional. Y esta conclusión no puede soslayarse acudiendo a un concepto «operativo» de frontera, distinto del consagrado en la legislación nacional e internacional (pp. 31-32).

$106 \mathrm{El}$ art. 22 LOEx reconoce a los extranjeros el derecho de asistencia jurídica gratuita y la asistencia de intérprete en todos los procedimientos administrativos que puedan llevar a su devolución, lo que garantiza el derecho de defensa, en particular la formulación de alegaciones y la presentación de recursos, extremo éste expresamente contemplado en el art. 21 LOEx.

107 Con el agravante de que últimamente ha crecido de forma exponencial el número de las personas que proceden de zonas de conflicto (de Siria en particular) y la mayoría de estas personas solicitan el estatuto de refugiado (I. Sánchez Amor, DSCD, cit., p. 63).

108 Vid. p. 47 del recurso. La orden de expulsión «ha de encontrar cobertura en la legislación de extranjería por imperativo de la 25.1 y respetar el derecho de defensa, dándose audiencia al extranjero» (STC 24/2000, de 31 de enero).

109 Estamos, en efecto, ante «una actuación administrativa que se lleva a efecto prescindiendo de manera plena del procedimiento establecido» (STS de 22 de septiembre de 2003, entre otras). En la misma línea, el Dictamen del Consell de Garanties Estatutaries explica que el precepto «regula un nuevo supuesto de expulsión...consistente en el rechazo de los ciudadanos extranjeros mientras intentan acceder a territorio español por lugares no habilitados, lo que, a diferencia de la expulsión propiamente dicha, la prohibición de entrada o el rechazo en la frontera y la devolución, medidas todas ellas previstas en la legislación de extranjería, no prevé ningún tipo de procedimiento ni de resolución administrativa, sino que se caracteriza por ser una actuación meramente fáctica y de inmediata ejecución». La literalidad del mis- 
ción, que no reúne los requisitos propios de un acto administrativo, «resulta arbitraria, con vulneración del artículo $9.3 \mathrm{CE}^{110}$, no sujeta a revisión judicial, en contra del artículo $106 \mathrm{CE}$, y priva al extranjero de su derecho a la tutela judicial efectiva al no garantizarle el acceso a los tribunales en condiciones que aseguren el efectivo ejercicio de sus derechos de defensa, como prescribe el artículo $24.1 \mathrm{CE}{ }^{111}$.

La nueva norma introducida en la LOEx no sólo impide la aplicación del principio de no devolución ${ }^{112}$ y el ejercicio del derecho de asilo (art. 13.4 CE), al impedir la identificación de personas necesitadas de protección internacional y el análisis individualizado de sus circunstancias, sino que impide asimismo la identificación de menores no acompañados, un colectivo especialmente vulnerable, y la subsiguiente aplicación de las previsiones de la LOEx y de la normativa protectora específica. Y tampoco permite la identificación y protección de las víctimas de trata que accedan a territorio español por puesto no habilitado ${ }^{113}$.

mo término «rechazo» lleva a concluir que se impide que los afectados puedan alegar cuáles son sus circunstancias personales (su condición de perseguido, por ejemplo, por motivos de raza u otros) y, lógicamente, que pueda haber un tratamiento individualizado para cada una de las personas rechazadas. De ahí que la Disposición examinada vulnere el derecho de asilo del artículo 13.4 CE, interpretado de acuerdo con la normativa internacional (art. 10.2 CE) y, en la medida que priva a los afectados del derecho al recurso y a la posterior tutela de los tribunales, vulnere también el artículo 24 CE (Dictamen, pp. 133-137).

110 Es la propia Ley la que habilita a la Administración para actuar arbitrariamente, al dejar esa decisión al libre arbitrio de las Fuerzas de Seguridad, cuya actuación resulta por tanto imprevisible.

111 Vid. p. 46 del recurso. El afectado por esta medida se ve privado de cualquier posibilidad de reacción frente a la expulsión. Además, por aplicación de la LOEX (artículo 58.7), la devolución lleva aparejada la prohibición de entrada durante tres años, por lo que tiene las mismas consecuencias de un procedimiento sancionador. Y si tiene la mismas consecuencias, el procedimiento ha de rodearse de las mismas garantías, sin que puede privarse a los extranjeros de los derechos de contradicción y audiencia, motivación y asistencia legal y al recurso (p. 50). En apoyo de esta tesis, se citan en el recurso las SSTEDH M.S.S. c. Bélgica y Grecia (2011), y A.S. y otros c. España (2014), que han declarado que las expulsiones por la vía de hecho imposibilitan el acceso a los procedimientos de extranjería, privando a los expulsados de la posibilidad de impugnar la ilegalidad de su expulsión y la vulneración de sus derechos.

112 Los recurrentes recuerdan (p. 54) que, de acuerdo con la jurisprudencia del TEDH, los Estados tienen la obligación de cerciorarse del trato al que pueden verse expuestos los migrantes que devuelven a sus países de origen o de procedencia, y evitar así que puedan verse sometidos a pena de muerte, a tortura o a otras penas o tratos inhumanos o degradantes. Del mismo modo, nuestro Tribunal Constitucional ha establecido esta misma limitación en relación con la entrega de ciudadanos a otros países (STC 140/2007). En un reciente informe, el Comité para Prevención de la Tortura (CPT) del Consejo de Europa ha recomendado a las autoridades españolas que no entreguen en ningún caso a los inmigrantes interceptados a las fuerzas auxiliares de Marruecos ante el riesgo de malos tratos (CPT/Inf (2015)19, apartado 14].

113 Vid. p. 55 del recurso. Esta disposición adicional pone en riesgo cierto y real los derechos a la vida y a la integridad física y moral de los así devueltos tanto por lo que supone esa vía, un trato degradante que atenta contra la dignidad de la persona, como por el hecho de que su expulsión y entrega a las autoridades marroquíes se consuma sin dar la oportunidad de exponer aquellas razones que pudieran justificar su presencia en el territorio español. Así pues, resulta contraria a los artículos 15, 24 y 106 CE (p. 56). La jurisprudencia del TEDH relativa al artículo 4 del Protocolo n. ${ }^{\circ} 4$, que prohíbe la expulsión colectiva de extranjeros, ha dejado muy claro que los Estados no pueden expulsar a un extranjero sin examinar antes sus circunstancias personales y permitirles presentar sus argumentos en contra de la medida adoptada por la autoridad competente. (Dictamen del Consell..., cit., p. 133). 
En realidad, como puso de relieve el senador Iglesias (IU), este régimen excepcional incurre en una contradictio in terminis, porque pretende legalizar el rechazo en frontera que se está realizando ya, pero al mismo tiempo se dice que habrá de hacerse respetando la normativa internacional, una normativa que lo proscribe, creando así más confusión si cabe ${ }^{114}$. Porque esa mención retórica a la normativa internacional de derechos humanos «no incorpora ningún procedimiento administrativo ni, por tanto, garantías para hacer efectivo el cumplimiento de esta normativa, por lo que no puede en ningún caso legitimar una vía de hecho, como la establecida en el apartado 1, que hace precisamente imposible la verificación eficaz de dichas previsiones normativas» ${ }^{115}$.

Numerosas organizaciones nacionales e internacionales de reconocida solvencia en materia de derechos humanos, como Amnistía Internacional, Human Rights Watch, la ACNUR, Cáritas, Cruz Roja, el Consejo General de la Abogacía Española o el Comisario para los Derechos Humanos del Consejo de Europa, han pedido la retirada de esta disposición, que desconoce los compromisos internacionales de nuestro país ${ }^{116}$.

Frente a este aluvión de críticas, el ministro se limitó a reiterar en el debate final celebrado en el Congreso que aquellas personas que se consideren con derecho a solicitar la protección internacional, sea el asilo o sea la protección subsidiaria, podrán hacerlo en los locales habilitados al efecto en la propia frontera, dando a entender que no podrán hacerlo fuera de esas oficinas ${ }^{117}$.

En su Recomendación sobre la LOPSC, la Defensora del Pueblo instó al Ministerio del Interior a desarrollar reglamentariamente el procedimiento estableci-

114 DSS, cit., p. 14057.

115 P. 56 del recurso.

116 El Convenio de Ginebra de 28 de julio de 1951 y el Protocolo, de 31 de enero de 1967, sobre el Estatuto de los Refugiados; el CEDH, la Carta de los Derechos Fundamentales de la UE; los artículos 12 y 13 de la Directiva Europea 2008/115, y el artículo 13 del Código de fronteras Schengen. Normas de Derecho internacional que forman parte de nuestro Derecho interno y gozan de una especial fuerza o resistencia pasiva. Sirva de nuevo como botón de muestra el reciente documento de la Comité de Derechos Humanos de la ONU, ya citado, que incluye un apartado sobre la expulsión de los solicitantes de asilo y los inmigrantes indocumentados, en el que puede leerse lo siguiente: «Al Comité le preocupa la práctica de devoluciones sumarias, también conocidas como «expulsiones en caliente», que tienen lugar en la línea fronteriza de la demarcación territorial de Ceuta y Melilla. En particular, el Comité nota con preocupación la disposición final primera de la Ley de Seguridad Ciudadana,... que establece un régimen especial a dichas ciudades autónomas autorizando dichos rechazos sumarios de inmigrantes». Esas expulsiones sumarias «se realizan sin las garantías suficientes para que se respete el principio de no devolución, cuando corresponda». Se insta por tanto a España a revisar la Ley de Seguridad Ciudadana y garantizar que todas las personas que solicitan protección internacional tengan acceso a procedimientos de evaluación justos e individualizados y a la protección frente a la devolución sin discriminación, y tengan acceso a un mecanismo independiente con autoridad para suspender las decisiones negativas» (Observaciones Finales..., cit., p. 6).

117 DSCD, cit., p. 66-67.Y acabó diciendo lo siguiente: «Tenemos 25 guardias civiles imputados en Ceuta y Melilla [por la muerte de 15 inmigrantes en la playa de Tarajal en febrero de 2014], y es obligación del Gobierno dotarles de la necesaria protección y seguridad jurídica para que puedan realizar la misión que tienen encomendada legalmente. Lo llevan haciendo así desde el año 2005. La única diferencia es que no se les había dado esta cobertura jurídica que ahora les damos nosotros». 
do en esta Disposición. Esa regulación debería contemplar «la necesidad de dictar una resolución administrativa, con asistencia letrada y de intérprete e indicación de los recursos que se podrán interponer contra ella» ${ }^{118}$.

TiTLE: The so called Ley Mordaza (Gag Law): The Organic Law 4/2015 of Citizen Security

ABSTRACT: The drafting process of the new LOPSC and its most relevant and controversial issues are analysed in this article. The draft bill, passed by the Government at the end of year 2013, was a text inspired by a very arguable understanding of public safety and sprinkled with several unconstitutionalities. And it was thus almost unanimously rejected. The critical remarks of the CGPJ, the Council of State, and other institutions forced the Government to revise and change the text. The final bill includes some positive developments, such as the regulation of the identification procedure, but it still contains some constitutionally doubtful provisions. Two of them are particularly serious: the one that sanctions the non authorized use of images and data of the Security Forces members and the Final Provision that provides for a special regulation of inmigrant expulsions in the borders of Ceuta and Melilla, giving legal coverage to the 'summary deportations'.

RESUMEN: En este artículo se analiza el proceso de elaboración de la nueva LOPSC y los aspectos más relevantes y polémicos de su contenido. El Anteproyecto, aprobado por el Gobierno a finales de 2013, era un texto inspirado en una concepción muy discutible de la seguridad ciudadana y salpicado de preceptos que no tenían encaje constitucional. Y suscitó por ello un rechazo casi unánime. Las observaciones críticas del CGPJ, del Consejo de Estado y de otros organismos e instituciones obligaron al Gobierno a revisar y depurar a fondo su articulado. El texto finalmente aprobado incorpora algunas novedades positivas, como la regulación de la diligencia de identificación, pero incluye algunas previsiones cuya constitucionalidad es más que dudosa. Dos de ellas revisten una especial gravedad: la que sanciona el uso no autorizado de imágenes o datos de los miembros de las Fuerzas de Seguridad y la Disposición Final que prevé un régimen especial en materia de expulsión en las fronteras de Ceuta y Melilla, para dar cobertura legal a las "devoluciones en caliente».

KEY WORDS: Citizen security, personal freedom (identification, custody), right of privacy (body searches), right of assembly, freedom of speech, foreigners expulsions.

Palabras CLAVE: Seguridad ciudadana, libertad personal (identificación, retención), derecho a la intimidad (registros corporales), derecho de reunión y manifestación, libertad de información; infracciones y sanciones administrativas, expulsión de extranjeros.

FECHA DE RECEPCIÓN: 01.10.2015 FECHA DE ACEPTACIÓN: 07.10.2015

118 En esa recomendación se propone también que en dicho procedimiento se deje constancia escrita de que «al extranjero se le ha facilitado información sobre protección internacional y que se ha verificado, mediante un mecanismo adecuado de identificación y derivación, las necesidades de protección internacional, que no es menor de edad o la concurrencia de indicios de que pudiera ser víctima de trata de seres humanos». Todo ello de conformidad con lo previsto en la Directiva 2013/32/UE de 26 de junio de 2013, sobre procedimientos comunes para la concesión o la retirada de la protección internacional. 